\title{
Compañeros de Jesús. El asesinato-martirio de los jesuitas salvadoreños.
}

\section{Jon Sobrino \\ Centro de Reflexión Teológica, San Salvador, El Salvador.}

Muchas veces me ha tocado escribir inmediatamente después de que ocurriera alguna tragedia en El Salvador: el asesinato de Rutilio Grande, de Monseñor Romero, de las cuatro religiosas norteamericanas, por citar los casos más impactantes. En todas estas ocasiones se juntaban dolor e indignación. De algune forma, sin embargo, los sobrevivientes lográbamos transformar relativamente pronto todos esos sentimientos en esperanza y en servicio; en mi caso, escribir y analizar teológicamente los acontecimientos, como suele decirse. Esta vez ha sido distinto. Para escribir se necesita claridad en la cabeza y aliento en el corazón, pero en este caso, durante varios días, la cabeza se me quedó vacía y el corazón, ciertamente, se me quedó helado.

Ahora, algunos días después, cuando poco a poco vuelve la serenidad, me pongo a escribir estas reflexiones. Lo hago como homenaje agradecido - pequeño e innecesario - a mis seis hermanos mártires, y lo hago también por si proporciona luz y ánimo a los que seguimos en este mundo, mundo cruel que mata a los pobres y a quienes echan su suerte con ellos, y mundo que quisiera matar también la esperanza de los vivos y paralizarlos.

Escribo de forma personal, pues en estos momentos, cuando todavía está muy fresco el recuerdo de mis hermanos asesinados, no sabria hacerlo de otra manera. Más adelante habrá que interpretar lo sucedido más reposada y analíticamente, pero ahora me sería imposible hacerlo así. Y prefiero hacerlo así, porque quizás de esta forma, bajo el impacto del dolor y del sentimiento de pérdida, pueda comunicar también un poco lo que han experimentado centenares de 
miles de salvadoreños. De 70 a 75,000 son los muertos en El Salvador, pero ahora, cuando me ha tocado de cerca, he sentido algo del dolor y de la indignación que han debido sentir tantos salvadorenos, campesinos, obreros, estudiantes, sobre todo madres, esposas, hijas, cuando les han asesinado a sus seres queridos.

En un primer momento voy a narrar con sencillez lo que sentí al enterarme de la noticia y durante los primeros días, en forma muy personal, como he dicho. Esta experiencia, no tiene mayor importancia en sí misma, pues es sólo una gota en el mar de lágrimas que es El Salvador, pero quizás sirva para comunicar el llanto del pueblo salvadoreño. Después ofreceré unas reflexiones globales sobre mis compañeros y sobre varias cosas importantes con las que me confronta su martirio. Hablaré de ellos como grupo, sobre todo de los cinco que trabajaban en la UCA a quienes mejor conoci; y si voy a mencionar un poco más a Ignacio Ellacuría es porque con él conviví más tiempo y fue él quien más habitualmente ponía en palabra lo que estos jesuitas aceptaban como fundamental en sus vidas $y$ trabajos.

\section{La experiencia más importante de mi vida}

Desde el 13 de noviembre estaba en Hua Hin, a unos 200 kilometros de Bangkok, Tailandia, dando un breve curso de cristología. Seguía por radio los trágicos acontecimientos de El Salvador y había logrado hablar por teléfono con los jesuitas. Todos estaban bien, me dijeron, y Ellacuría ya había regresado de Europa y habia entrado en el pars sin problemas. Ese mismo lunes 13, la Fuerze Armada había registrado nuestra casa, cuarto por cuarto, y el Centro Monseñor Romero de la UCA, pero sin mayores consecuencias.

A última hora de la noche del 16 de noviembre - serían las 11 de la mañana en Sen Salvador- un sacerdote irlandés me despertó. Había oído, medio dormido, las noticias de la $B B C$ que hablaban de que algo serio les había sucedido a los jesuitas de la UCA en El Salvador. Para cerciorarse, llemó por teléfono a Londres y entonces me despertó. "Ha sucedido algo terrible," me dijo. "No está muy claro, pero parece que han asesinado a algún jesuita de la UCA, no sé si es el rector. Desde Londres te informarán mejor."

De camino al teléfono pensé, aunque no quería aceptarlo, que habían asesinado a Ignacio Ellacuría, y pensé cuántas veces habíamos temido que eso ocurriera. Realmente Ellacuría habra sido, sin demagogia, con objetividad, con la palabra de verdad y con la valentía y tenacidad que siempre lo caracterizó, un auténtico profeta 
en sus escritos y, cada vez más, públicamente por televisión. Hacía poco tiempo, una señora del pueblo me había dicho después de verlo en televisión: "Desde que asesinaron a Monseñor nadie ha hablado tan claro en el país." Todo estos pensamientos pasaron por mi mente durante el breve camino al teléfono.

Al otro lado de la línea, en Londres, me hablaba un gran amigo mío y de todos los jesuitas de El Salvador, y un gran solidario con el paía y con la Iglesia. Comenzó con estas palabras: "Ha ocurrido algo terrible." "Ya sé," le contesté. "Ellacuría." Pero no sabía. Me preguntó si estaba sentado y si tenía algo para escribir. Le dije que sí, y entonces me contó lo que había sucedido. "Han asesinado a Ignacio Ellacuria." Me quedé en silencio y no escribí nada, pues ya me lo temía. Pero mi amigo continuó: "Han asesinado a Segundo Montes, Ignacio Martín-Baró, Amando López, Juan Ramón Moreno y Joaquín López y López." Mi amigo lera los nombres despacio y cada uno de ellos iba resonando como un martillazo que recibía en total impotencia. Yo los iba escribiendo esperando que la lista terminase después de cada nombre que iba mencionando. Pero no, a cada nombre seguía otro, y así hasta el final. Toda la comunidad, toda mi comunidad había sido asesinada. Además, con ella también fueron asesinadas dos mujeres. Vivían en una casita que estaba a la entrada de la universidad y, por miedo a la situación, pidieron a los padres pasar la noche en nuestra casa donde se sentían más seguras. También ellas fueron asesinadas inmisericordemente. Sus nombres son Julia Elba, cocinera de los jesuitas durante anos, y su hija Celina de 15 años. Como en el caso de Rutilio Grande, con quien fueron asesinados dos campesinos, también aquí murieron dos sencillas mujeres del pueblo salvadoreño con los jesuitas.

Después mi amigo de Londres me fue dando los detalles proporcionados por los cables internacionales. Los autores fueron alrededor de 30 hombres vestidos de militar. Me dijo que a tres de los jesuitas los habian sacado al jardín y alli los habian torturado y ametrallado. A los otros tres y a las dos mujeres los habian ametrallado en sus camas. Mi amigo no sabía cómo continuar hablando. Como muchos otros, esos días no tenía palabras para expresar lo acurrido. Procuró darme unas palabras de consuelo y de solidaridad y terminó preguntándose qué extraña providencia había permitido que yo no estuviera en nuestra casa en aquellos momentos.

Pasé varias horas, mejor dicho varios dias, sin poder reaccionar. Como he dicho al principio, en otras ocasiones trágicas relativamente pronto recobramos el ánimo y se apoderaba de nosotros un sentido 
de servicio que nos hacía activos, lo que de alguna forma aliviaba nuestro dolor y desviaba de nuestras cabezas escenas de terror. Las misas que celebrábemos por los mártires nos llenaban incluso de gozo. Pero esta vez para mi fue distinto. La distancia me hacia sentirme impotente y solo. Y, sobre todo, los seis jesuitas asesinados eran mi comunidad, eran de verdad mi familia. Juntos habíamos vivido, trabajado, sufrido y gozado durante muchos anos. $Y$ ahora todos estaban muertos.

Creo que nunca he sentido nada semejante. Al sacerdote irlandés que me acompańo aquella noche le dije que era lo más importante que me habra sucedido en la vida. Y creo que no es exageración. Mis largos años en El Salvador, mis trabajos, incluso con riesgos y conflictos, el haber pasado por situaciones dificiles, más aún, mi propia vida religiosa y sacerdotal, me parecían cosas mucho menos decisivas que la muerte de mis hermanos y poco reales en comparación con esas muertes. Experimenté un corte real en mi vida y un vacio que no se llenaba con nada. En aquellos momentos recordé el pasaje bíblico de las madres de los niños asesinados que lloraban sin encontrar consuelo. Cuando venían a mi mente las cosas de mi vida normal, escribir, dar charlas y clases, las cosas que he hecho en los últimos 16 años en El Salvador y lo que podía hacer en el futuro, todo me parecía cosa irreal que nada tenía que ver con la realidad. La realidad más real -como he escrito muchas veces desde El Salvador- es la vida y la muerte de los pobres. A miles de kilómetros de distancia, y aunque yo estaba vivo, la muerte de mis hermanos me confrontaba con una realidad en comparación con la cual todo lo demás me parecía poca cosa, nada. $O$, por decirlo más exactamente, con una realidad que me forzaba a mirar desde ella todo lo demás. La Iglesia, la Compañía, la fe no eran para mi realidades en esos momentos desde las cuales -como distantemente- podía yo comprender o interpretar su muerte, sino al revés: desde esas muertes todas esas realidades se me hacían pregunta, y poco a poco, lo digo con agradecimiento, también respuestas a lo que es lo más fundamental de nuestras vidas: Dios, Jesús, la vocación, el pueblo salvadoreño.

Me preguntaba también por qué estaba yo vivo y la misma pregunta me hizo el sacerdote irlandés que estaba conmigo. Se me ocurrió ponerlo en palabras tradicionales: "no soy digno." Pero en verdad no había respuesta al por qué y tampoco me ocupó largo tiempo ese pensamiento. En su lugar empecé a tener un sentimiento de pérdida irreparable. Nunca será lo mismo la UCA ni nunca seré yo el mismo. Después de tantos años de vivir y trabajar con esos 
hermanos se me había hecho como segunda naturaleza contar con ellos para mi propia vida y trabajo. Cualquier idea, cualquier plan que me venía a la cabeza, siempre terminaba en lo mismo: ya no están. Ya no está Ellacurfa para terminar el libro que estábamos editando juntos, ya no está Juan Ramón para organizar el curso de enero sobre Monseñor Romero, ya no esté Amando para terminar el próximo número de la Revista Latinoamericana de Teologla, ya no está Nacho para dar el curso de psicologia de la religión que le había pedido para la maestría en teología, ya no está Montes para conocer los problemas de los refugiados y de los derechos humanos, ya no está Lolo —así llamábamos al P. Joaquín López y López-, silencioso normalmente, pero con gran olfato para conocer qué piensa y qué espera la gente pobre con la que trabajó en Fe y Alegría. Los ejemplos que he puesto no son importantes por sí mismos, por supuesto; pero con ello quiero indicar que sentía que habfa perdido las relaciones inmediatas que me unían a la vida real. $Y$ me acordé que en los anos de estudio de filosofía algún autor - no recuerdo quién- definía no sé si la muerte o el infierno como la ausencia total de relaciones.

Esta fue mi experiencia en las primeras horas y días. Fue lo más fuerte que sentí, sin ninguna duda, pero tampoco fue lo único. A la mañana siguiente, los participantes en el curso se me acercaron y abrazaron en silencio y muchos de ellos con lágrimas. Uno de ellos me dijo que la muerte de mis hermanos era la mejor explicación y confirmación de la clase que habíamos tenido el día anterior sobre Jesús, el siervo doliente de Jahvé, y el pueblo crucificado. El comentario me animó un poco, no porque se refiriera con aprobación a mi teología, por supuesto, sino porque hermanaba a mis hermanos jesuitas con Jesús y con los oprimidos. Esa misma mañana tuvimos una misa en Hua Hin, con un altar hecho con flores, al bello estilo asiático, donde estaba escrito el nombre de El Salvador y donde había también ocho candelas que personas de diferentes países asiáticos y africanos -que saben de dolor y muerte- fueron encendiendo mientras yo pronunciaba los nombres de las ocho personas asesinadas. En la noche, en otra ciudad a cinco horas de carro, tuve otra misa con varios jesuitas y muchos colaboradores laicos que trabajan con refugiados de Viet Nam, Burma, Cambodia, Filipinas, Corea... Ellos también saben de sufrimiento y pudieron entender lo que ocurria en El Salvador. El sábado y el domingo, ya en Bangkok, tuve dos charlas - tal como me lo habían pedido de antemanosobre Jesús y los pobres. Personalmente no tenía muchas ganas de hablar, pero pensé que se lo debía a mis hermanos y nada mejor que 
hablarles de ellos para presentar hoy la vida y muerte de Jesús de Nezaret por su compromiso con los pobres. Por cierto, en Tailandia, país con un pequeñ́simo número de cristianos, alguien me preguntó con ingenuidad y sin poderlo creer: " $\ Y$ en El Salvador hay catolicos que asesinan sacerdotes?"

No todo fue, pues, oscuridad y soledad. Empecé a conocer las reacciones en muchos lugares, la solidaridad de muchos jesuitas en todo el mundo, las palabras claras de Monseñor Rjvera, la promese del P. Kolvenbach, nuestro superior general, de venir a El Salvador en navidad, el ofrecimiento inmediato de varios jesuitas de otros parses para venir a El Salvador y proseguir la obra de los asesinados, la misa en el Gesú, iglesia de los jesuitas en Roma, con unos 600 sacerdotes en el altar, otra misa en Munich con más de 6,000 estudiantes, las misas en Estados Unidos, España, Inglaterra, Irlanda y tantas otras en todo el mundo. Recibí también cartas y llamadas telefónicas, llenas de lágrimas y de dolor, pero llenas de amor y agradecimiento hacia los seis jesuitas. $Y$ cuando me contaron cómo había sido la misa del entierro, en la capilla de Monseñor Romero y con unos jesuitas decididos a seguir adelante con el trabajo de la UCA, poco a poco me volvió la luz y el ánimo. Por lo que he ido conociendo, la reacción humana y cristiana a este asesinato ha sido única, sólo comparable quizás a la del asesinato de Monseñor Romero - políticamente no hay duda que es el asesinato que ha originado mayor revuelo después del de Monsefior Romero. En varios paŕses, me dicen, nada ha galvanizado tanto a los jesuitas, como estos martirios. Si esto ha sido así, se puede decir sin triunfalismos que este martirio ya ha empezado a producir bienes, y esto es lo que ahora mantiene nuestra esperanza, aunque no desaparece del todo el dolor y el sentimiento de pérdida.

Si he contado esta experiencia, es para decir que ahora entiendo un poco mejor lo que significan las victimas de este mundo. Las cifras -70,000 en El Salvador- son escalofriantes, pero cuando esas victimas tienen nombres concretos y han estado muy cercanas a uno, el dolor es muy grande. Lo he contado también para decir con sencillez que he querido mucho a esos hermanos asesinados y mártires, y que les estoy muy agradecido por lo que me dieron en vida y por lo que me han dado con su muerte. Y lo he contado, por último, para que se entienda que lo que voy a decir a continuación -que no tiene nada de espectacular, sino de cosas bien sabidas- lo hago con honradez y sinceridad, sin ninguna rutina sino con la convicción que le otorga esta trágica circunstancia. Voy a decir primero unas palabras sobre quiénes eran estos jesuitas y después 
haré algunas reflexiones sobre cosas importantes que quedan muy iluminades por su muerte.

\section{LQuiéné eran?}

Muchas cosas podria decir de ellos. Cuando se escriban sus biografias, algunas, como la de Ellacuría, el rector de la universidad, llenarán varios volúmenes, pues su vida, 59 años, fue de una prodigiosa creatividad intelectual, eclesial, religiosa y de enálisis político-social. Otras, como la del P. Lolo, podrán ser más breves, no porque en su larga vida, 70 años, no hiciera muchas y buenas cosas en el colegio Externado Sen José, en los primeros años de la UCA y en sus veinte últimos años al servicio directo de los pobres en $\mathrm{Fe} y$ Alegria, sino porque por su talante sencillo y humilde él siempre quiso pasar inadvertido. $E$ infinidad de coses se dirán de los demás. Segundo Montes, 56 años, sociologo, muchos años en el colegio y en la UCA, investigador de la problemática popular, sobre todo de los refugiados, director del Instituto de Derechos Humanos de la UCA. Nacho Martín-Baró, 47 anos, vicerrector académico, psicólogo social atento a la problemática del pueblo pobre, a las consecuencias psicosociales de la pobreza y de la violencia, a la religiosidad liberadora. Juan Ramón Moreno, 56 años, maestro de novicios, profesor de teología, subdirector del Centro Monseñor Romero, que fue por cierto parcialmente destruido el mismo día de los asesinatos. Amando López, 53 años, rector del seminario diocesano de San Salvador, rector del colegio y de la universidad de Managua durante la revolución sandinista, profesor de teologla de la UCA Y junto a estos "títulos" habrá que mencionar los desvelos de todos ellos en su vida diaria por atender a la gente popular que se acercaba con sus problemas, su pastoral dominical en parroquias y comunidades pobres, suburbanas y rurales, Santa Tecla, Jayaque, Quezaltepeque, Tierra Virgen, sus desvelos por construir en esos lugares pobres una pequeña clínica, una guardería infantil, o poner un tejado de lámina sobre unos palos para convertirlo en iglesia. También habrá que escribir las biografias de Julia Elba y Celina, quizás en pocas páginas, pero preñadas de realidad salvadoreña y cristiana, de pobreza y sufrimiento, de trabajo diario para sobrevivir, de esperanza de justicia y de paz, de amor a Monseñor Romero, de fe en el Dios de los pobres.

Sin pretender, pues, ahora ofrecer una biografía de ellos, quisiera decir algunas palabras sobre lo que más me ha impresionado de este grupo de jesuitas como grupo -aunque obviamente existían diferencias entre ellos - y ofrecerlas como la más importante herencia 
que nos dejan.

Ante todo, eran seres humanos, salvadoreños, que intentaron vivir honrada y responsablemente en medio de la tragedia y la esperanza del país. Y aunque no parezca esto suficiente alabanza para mártires gloriosos, por ahí quiero empezar, pues vivir en medio de la realidad salvadoreña, como en toda la del tercer mundo, es antes que nada asunto de humanidad, exigencia a todos a responder con honradez a una realidad deshumanizada, que clama por la vida, y que en sf misma es cuestionamiento ineludible a nuestra propia humanidad.

Pues bien, estos jesuitas eran muy salvadoreñamente humanos, hombres de una pieza, no como caf́as que menea cualquier viento. Trabajaban de sol a sol y ahora se habrán presentado ante Dios con sus manos callosas, si no de trabajos físicos sí de todo tipo de trabajos: clases, escritos, importante aunque monótono trabajo administrativo, misas, retiros, pláticas, entrevistas, viajes y conferencias en el extranjero... A veces con gran brillantez, participando en congresos internacionales, o apareciendo en televisión, hablando con reconocidas personalidades, diplomáticos y embajadores, obispos, líderes políticos y sindicales, intelectuales, recibiendo premios internacionales $\rightarrow$ Segundo Montes recibió un premio, en un local del congreso de Estados Unidos, por su investigación sobre los refugiados el día 1 de noviembre, y Ellacuría, pocos días antes de regresar a El Salvador, recibió de manos del alcalde de Barcelona un importante premio otorgado a la UCA... A veces, en las parroquias, en las comunidades y en sus oficinas, hablando con la gente sencilla, con campesinos y refugiados, con madres de desaparecidos, tratando de resolver los problemas cotidianos de la gente pobre... A veces - la mayor parte de su tiempo- siguiendo la monotonía del calendario - aunque en El Salvador casi ningún día se parece a otro-, trabajando en el día a día, respondiendo a esa estructura de la realidad que se llama "tiempo," acumulando en ese trabajo diario un gran conocimiento del país y la credibilidad de estar siempre allí en su puesto, lo cual les otorgó un gran prestigio y potenció inmensamente su trabajo y su eficacia.

Eran hombres de espíritu, aunque externamente no eran de los convencionalmente llamados "espirituales." De Ellacuría aprendí la expresión "pobres con espíritu" para relacionar adecuadamente pobreza y espiritualidad. A estos jesuitas quisiera llamarlos ante todo "hombres con espíritu." $Y$ ese espíritu se manifest6, como san Ignacio dice en la meditación para alcanzar amor, "más en obras que en palabras." 
Ante todo, espíritu de servicio. Si algo quedaba claro de esta comunidad era su trabajo, hasta tal punto que nos llamaban fanáticos. Pero un trabajo que era realmente servicio. En esto fueron ciertamente insignes seguidores de san Ignacio, no pensando en el trabajo como modo de hacer carrera - varios de ellos muy bien pudieran haber sido figuras mundiales en su profesión y algunos llegaron a serlo, aunque sin buscarlo nunca directamente- ni porque no deseasen paz y descanso. Pero, dadas las exigencias del pars y la creatividad de Ellacuría sobre todo para proponer siempre nuevos planes y no dormirnos nunca en los laureles, el trabajo es lo que dominaba la comunidad, con las desventajas que eso tiene, pero sobre todo con el testimonio de una vida dedicada a servir. Casi todos tenían trabajo pastoral en parroquias y comunidades pobres los domingos después de una semana agotadora, y muchos sábados y domingos por la tarde se los podía ver trabajando en sus oficinas. Recuerdo, por ejemplo, que a veces surgia la discusión sobre terminar el trabajo semanal de la UCA el viernes por la tarde, y no el sábado al mediodia, como en realidad lo hacemos, pero la discusión terminaba siempre con estas palabras: "Eso es para el primer mundo. En un país pobre como el nuestro, hay que trabajar más, no menos." De hecho, hasta el concepto mismo de vacaciones y, nada digamos, de año sabático, llegó a desaparecer de nuestras vidas. $Y$ aunque este trabajo, realmente excesivo, tiene también su aspecto deshumanizante y costos para la salud, así vivian estos hombres porque el desvivirse trabajando era cuestion de humanidad, de responder a las innumerables y urgentes exigencias de la realidad salvadoreña. Recuerdo que, cuando el P. Kolvenbach nos visitó a los jesuites de El Salvador en 1988 - visita muy animante que agradecimos sinceramente-, nos recomendó, como a él le toca hacerlo, que no trabajásemos en exceso, que cuidásemos las fuerzas y la salud. Y recuerdo que alguien de la comunidad le contesto que en situaciones como las nuestras hay que estar indiferente a salud o enfermedad, a vida corta o larga, como dice san Ignacio en "el principio y fundamento." No es que no comprendiésemos y agradeciésemos lo que nos decía el P. Kolvenbach, pero queríamos insistir en que la realidad salvadoreña - no solo los pensamientos ascéticos o místicos- exige esa indiferencia y esa disponibilidad para dejar la vida y la salud hecha girones. Exagerados o no, estos hombres vieron en el trabajo la forma de servir y de responder a la realidad salvadoreña.

Ese trabajo, sin embargo, tenía una finalidad muy determinada: el servicio a los pobres. Cuando usábamos lenguaje religioso 
hablábamos de los pobres, los privilegiados de Dios. Cuando usábamos lenguaje histórico salvadoreño, hablábamos de las mayorías populares. En realidad es una misma cosa: el servicio a millones de hombres y mujeres que llevan una vida indigna de seres humanos y de hijos e hijas de Dios. En este servicio hay que encontrar lo más profundo de sus vidas y por ello puede decirse que este grupo de jesuitas tenía en verdad espíritu de compasión y misericordia. Si trabajaban como fanáticos y corrían riesgos muy conscientemente era porque se les removian las entrafias -como al buen samaritano, como a Jesús y como al Padre celestial- al ver a todo un pueblo herido en el camino. Nunca dieron un rodeo, como el sacerdote y el levita de la parábola, para no encontrarse y dejarse afectar por el sufrimiento del pueblo. Nunca dijeron que no a las continuas peticiones de la gente, mientras fuese posible complacerlas. Nunca buscaron subterfugios en el trabajo académico para no hacerlo, como si el saber universitario no estuviera también sometido a la exigencia primaria ética y práxica de responder al clamor de las mayorías populares. Por eso, la fuente, exigente e inspiradora, de todo su trabajo y de todo su servicio fue esa compasión y misericordia que se les convirtió en algo verdaderamente primero y último. El lenguaje que usaban como universitarios era el de "justicia," "transformacion de estructuras," "liberación," incluso, bien entendido, el de "revolución;" pero no era éste un lenguaje frío, puramente ideológico o político, sino que detrás de él estaba el lenguaje de verdadero amor hacia el pueblo salvadoreño, el lenguaje de la misericordia. Con este pueblo y para este pueblo vivieron muchos años. Y de este pueblo todos ellos hicieron su pueblo, habiendo nacido, con la excepción del padre Lolo, en España. "Tu pueblo será mi pueblo," como dice la Escritura.

Eran hombres con espiritu de fortaleza. Tenian temple y aguante para todo, para los duros y constantes trabajos, para atender a los mil y un problemas que diariamente pasaban por la universidad, los que eran estrictamente de la universidad y los que a diario generaba el país y que llegaban a la universidad. Así, tenían que mezclar clases con ayuda urgente a algún refugiado o desaparecido, tenían que interwumpir mil veces los escritos que tenían entre manos con llamadas y visitas. No había mucha paz externa para trabajar, a veces parecía que las espaldas no eran ya suficientemente anchas para aguantar todo lo que se venía encima; pero no se ajslaban ante los problemas ni desfallecían.

$Y$ tenian fortaleza para mantenerse en los conflictos y persecuciones. En los últimos quince años abundaron las amenazas en 
llamadas telefónicas y cartas anónimas, y sobre todo en los periódicos donde se hicieron acusaciones alucinantes en editoriales, campos pagados -a veces de la Fuerza Armada- los cuales terminaben de una u otra forma insinuando o pidiendo claramente la expulsión o la eniquilación de estos jesuitas. En los últimos meses aparecieron claras amenazas en la prensa y la televisión sobre todo contra Ellacuría y Segundo Montes. Las últimas amenazas fueron por radio, cuando desde el 12 de noviembre todas las emisoras estaban en cadena gubernamental y proferian amenazas contra ellos y el arzobispo.

$\mathrm{Y}$ junto a las amenazas verbales, los ataques físicos. Desde el 6 de enero de 1976 - recuerdo muy bien la fecha- cuando estallo la primera bomba en nuestra universidad, en otras quince ocasiones han puesto bombas, en la imprenta, en el centro de cómputo, en la biblioteca, en el edificio de administración. La última estalló el 22 de julio de este año destruyendo parcialmente la imprenta. En nuestra propia casa, la policía entró cuatro veces y la última vez estuvo allí once horas. En febrero de 1980, la casa fue fuertemente ametrallada a la noche, y en octubre de ese mismo año fue dinamitada dos veces: el día 24 y, tres días después, el 27. En 1983, una nueva bomba explotó en nuestra casa; esta vez por defender el díálogo como solución más humana y cristiana para el pass. Trágica ironía, pero en aquellos días la misma palabra "diálogo" era sinónimo de traición.

Su servicio a las mayorías populares era, pues, muy consciente de los riesgos que traía consigo. Y ese riesgo lo asumieron con absoluta naturalidad, sin alharacas, ni siquiera tras un especial discernimiento espiritual, pues sólo se discierne lo que no está claro, y para estos hombres era absolutamente claro que tenían que proseguir su trabajo en el pars. Por ello permanecieron en El Salvador y nunca los escuché que pensasen abandonarlo ante tantas amenazas y peligros, y quizás el mero hecho de quedarse en el pars fue un gran servicio para mucha gente que se hubiese ido si ellos hubiesen abandonado el pars. En 1977, después de que asesinaron a Rutilio Grande, todos los jesuitas fuimos amenazados de muerte. En las listas de personas peligrosas siempre estaban varios nombres de los jesuitas de la UCA. Y recuérdese que en El Salvador se llegó a lanzar folletos por la calle con estas palabras: "Haga patria, mate un cura." Algunas temporadas solíamos pasar la noche en casas de religiosas y de familias amigas, pero a la mafiana siguiente todos volvíamos a nuestro trabajo de la UCA. S6́lo en noviembre de 1980 salió del pars Ellacuría bajo protección de la embajada española, pues "י nombre era el primero en una lista secreta con nombres de 
personas que iban a ser asesinadas. $Y$ recuérdese que ese ano las amenazas eran muy reales; fue el año en que fue asesinado Monseñor Romero, cuatro sacerdotes, cuatro religiosas norteamericanas, un seminarista, el rector de la Universidad Nacional, los cinco máximos dirigentes del Frente Democrático Revolucionario, y, como siempre, centenares de campesinos, obreros, sindicalistas, estudiantes, maestros, médicos, periodistas... Ellacuría regresó después al para sin ninguna garantía, asumiendo él mismo todos los riesgos.

No cabe ninguna duda, pues, que eran hombres de temple, de una pieza, como el pueblo salvadoreño que los fue moldeando y que ha dado un ejemplo al mundo de cómo aguantar infortunios sin cuento, cómo sobrevivir y cómo luchar por la vida, con una creatividad que asombra a todos los que los conocieron. Estos hombres fueron, pues, en verdad salvadoreños, y quisiera añadir que la honradez, el servicio y la fortaleza con que vivieron la recibieron en muy buena medida de este pueblo. Sus dolores los convirtieron y purificaron, de su esperanza vivieron y su amor los sedujo para siempre.

Estos hombres eran también creyentes, cristianos. No lo menciono aquí como cosa obvia y rutinaria, sino como algo central en sus vidas y como algo que en verdad las dirigí completamente. No eran de los que convencionalmente podriamos llamar el tipo "piadoso," repitiendo en el templo "Señor, Señor," sino de los que iban a la calle a hacer la voluntad de Dios. Por ello, cuando en la comunidad hablábamos de cosas de la fe, las palabras eran más bien parcas, pero muy reales. Solíamos hablar del reino de Dios y del Dios del reino, de la vida cristiana como seguimiento de Jesús, del Jesús histórico, el de Nazaret, pues no hay otro. En la universidad en la enseñanza y en los escritos de teologia por supuesto-, pero también en momentos solemnes y en actos públicos se recordaba nuestra inspiración cristiana como algo central, como lo que daba vida, dirección, ánimo y significado a todos nuestros trabajos, y como lo que explicaba también los riesgos que conscientemente corría la universidad. Se hablaba con toda claridad del reino de Dios y de la opción por los pobres, del pecado y del seguimiento de Jesús. Esta inspiración cristiana de la universidad la exponían esos jesuitas sin ninguna rutina, y la gente captaba que en verdad esa inspiración es lo que dirigia la universidad. Incluso algunos no muy explícitamente creyentes lo captaban y agradecían, porque a través de la fe cristiana asf vivida la universidad se hacía más salvadoreña.

Es dificil, por no decir imposible, penetrar en lo más hondo del corazón de esos hombres, en su fe, pero para mí no hay duda que 
fueron grandes creyentes y que su vida solo tenía sentido como seguidores de Jesús. ¿Cómo era su fe? Pensando en cada uno de ellos, con sus diferentes historias y caracteres, me siento fascinado y agradecido ante todo por el hecho mismo de que tuvieron una gran fe, pues - digámoslo de paso- en parses como El Salvador, la fe no es cosa obvia en medio de tanta injusticia y de tanto silencio de Dios, y no puedo menos de impresionarme por el hecho mismo que haya fe.

Creyeron en un Dios de vida, bueno para los pobres, utopia benéfica en medio de nuestra historia, que proporciona sentido y salvación a nuestras vidas, y de ahí su esperanza radical. Creo que encontraron a Dios escondido en el rostro doloroso de los pobres y lo encontraron crucificado en el pueblo crucificado. Y que también encontraron a Dios en esos gestos de resurrección, grandes y pequeños, de los pobres. $Y$ en ese Dios empequenecido $\rightarrow$ el Dios siempre menor- encontraron al Dios siempre mayor, verdadero misterio inabarcable que les impulsaba a recorrer caminos nuevos, no transitados, a preguntarse qué es lo que hay que hacer. De ellos quisiera decir lo que en otros lugares he escrito de Jesús de Nazaret. Para ellos Dios fue Padre bueno, utopía benéfica para la historia, que la atrae y hace que dé más de sí, y en él podían descansar, depositar el sentido último de sus vidas. Y para ellos el Padre seguía siendo Dios, misterio inmanipulable, y por ello no los dejaba descansar y los impulsaba a buscar siempre cosas nuevas que hacer para responder a su nueva y soberana voluntad.

Ya he dicho que nuestra comunidad no era muy dada a poner en palabra estas cosas, sino a decirlas con la propia vida, y ahora mis hermanos las han dicho con su propia sangre. Pero quiero mencionar algo de lo que sí hablábamos con frecuencia: de Monseñor Romero. Y ése era lenguaje de fe. Querer y admirar a Monseñor Romero no es cosa en absoluto difícil, a no ser para los que niegan la luz y tienen un corazón de piedra, pero intentar seguirlo y aceptar a todo Monseñor Romero es cosa de fe. Creo que para ellos, para mi y para tantos otros, Monseñor Romero fue un Cristo actualizado $y$, como Cristo, sacramento de Dios. Confrontarse con Monseñor Romero era como confrontarse con Dios.

Encontrar en la vida personal a Monseñor Romero era como encontrar a Dios. Intentar seguir a Monseñor Romero era como seguir a Jesús hoy en El Salvador. $Y$ eso es lo que mis hermanos intentaron hacer. No creo que ni el Señor Jesús ni el Padre celestial estén celosos de que hable así de Monseñor Romero. Al fin y al cabo, él ha sido su don más precioso en nuestros días para todos nosotros. 
Y cuando alguien se siente absolutamente atrafdo por un testigo como Monseñor Romero, a quienes hemos visto, ofdo y tocado, creo que puedo decir con sinceridad que se siente atrardo por Jesuls y por su evangelio, de quien solo hemos leído sin verlo, de manera definitiva.

En cualquier caso, si es verdad que todos vivimos nuestra propia fe llevados por la fe de los demás, no tengo ninguna duda que nuestra comunidad era llevada por la fe de otros, de nuestro hermano Rutilio Grande, de tantos creyentes salvadoreños que han mostrado con su sangre su verdadera fe $y$ de la fe de Monseñor Romero. No sé si estoy proyectando en otros lo que para mí es la fe en Dios, pero creo y espero que no sea mera proyección. Si algo he aprendido en El Salvador es que la fe es, por una parte, realmente indelegable, como le de Abraham solo ante Dios, pero, por otra, es una fe llevada por otros. Las dos cosas se combinan en El Salvador, las dos se apoyan mutuamente, y de esta manera en medio de tanta oscuridad sigue siendo posible, creo yo, la luz de la fe. Como dice el profeta Miqueas, en una cita que muchas veces he usado, queda muy claro lo que Dios desea de nosotros seres humanos: "practicar la justicia y amar la lealtad." Y queda claro también -ahora en el claroscuro del misterio- que asi "caminamos humildemente con Dios en la historia." Lo primero, la absoluta exigencia de justicia, es lo que les iluminó con toda claridad la realidad de los pobres y practicando la justicia- lo que les hizo corresponder a Dios. Lo segundo, el difícil caminar con Dios en esta historia de tinieblas - ide dónde sacar fuerzas para ello? - creo que se los posibilitó el recuerdo de Jesús, de sus testigos actuales y la fe de los mismos pobres. Estos hermanos se entroncaron en esa corriente esperanzada y amorosa que sigue presente en la historia a pesar de todo, en esa corriente de la historia que protagonizan en último término los pobres. Ellos trabajaron para que esa esperanza utópica fuese cada vez mayor y tomase más cuerpo, pero ella también los llevó a ellos en su esperanza y en su fe. Creo que ellos miraron a los pobres desde Dios y con ellos caminaron hacia Dios. Así era, creo yo, la fe de mis hermanos.

Estos hombres y creyentes fueron por último jesuitas. Creo que fueron profundamente "ignacianos," aunque no pareciesen a veces muy "jesurticos," si se me entiende bien, de los que están pendientes de la última información que viene de la curia, o de esos que piensan que la Compañía es lo más importante que existe sobre la faz de la tierra, aunque estaban sinceramente orgullosos de ser jesuitas. No es que fueran insignes en todo lo ignaciano, pero sí creo que fueron 
ingignes en las cosas fundamentales de los Ejercicios Espirituales. Recuerdo que en 1974, Ellacuría y yo dimos un curso sobre los Ejercicios vistos desde América Latina. Y en 1983 juntos escribimos un documento que hicimos en nuestra Congregación Provincial para ser presentado a la Congregación General de ese mismo año, basado en la estructura de los Ejercicios. Normalmente nos tocaba a nosotros dos y a Juan Ramón Moreno poner en palabra lo ignaciano de nuestras vides y trabajos, pero creo que todos los demás aceptaban y participaban cordialmente de esa visión.

De san Ignacio solfamos recordar los grandes momentos de los Ejercicios. La contemplación de la encamación, para ver nosotros el mundo resl con los ojos del mismo Dios, es decir, mundo de perdición, y para reaccionar con las entrañas del miamo Dios, es decir, "hacer redencion." Y esto es importante recordarlo porque, como para muchos otros salvadoreños, no fue la cólera -que tantas veces estaba más que justificada - ni la venganza ni mucho menos el odio lo que fue el motor de sus vidas, sino el amor: el "hacer redención" como dice san Ignacio. Solíamos recalcar también la misión de Jesús al servicio del reino de Dios e historizarla para nuestros días; la meditación de las dos banderas con la alternativa insuperable de riqueza y pobreza, con la intuición ignaciana de que la pobreza, cristianamente asumida, lleva de por sí a todos los bienes, mientras que la riqueza, por su propia naturaleza, lleva a todos los males; el cargar con el pecado del mundo y el escondimiento de la divinidad de Cristo en la pasión, como dice san Ignacio. Y algo que fue muy original y sumamente actual es la interpretación que hizo Ignacio Ellacuría del coloquio de la meditación de los pecados ante Cristo crucificado. En una interpretación historizada para nuestro tercer mundo, se preguntaba que hemos hecho para que estos pueblos estén crucificados, qué hacemos ante sus cruces y qué vamos a hacer para bajarlos de la cruz. De él aprendí también a aplicar a nuestros pueblos la expresión "pueblo crucificado" - no s6́lo hay que hablar del "Dios crucificado" de Moltmann, solía decir, aunque esto sea necesario- y la comparación de esos pueblos con el siervo doliente de Jahvé, como lo hizo también intuitivamente Monseñor Romero: el siervo doliente es Jesús y el siervo doliente es el pueblo crucificado. En la respuesta a estas preguntas se expresaba la conversión que exige san Ignacio con total seriedad.

También reinterpretamos el ideal de san Ignacio: "contemplativos en la acción" como "contemplativos en la acción de la justicia." No sé cuánto había de contemplación en sus vidas, tal como ésta se entiende convencionalmente, pero no dudo que el lugar privilegiado 
de su contemplación, de encontrar realmente el rostro de Dios en este mundo, estabe en su acción para cambiar el rostro de Dios, oculto y desfigurado en los pobres y oprimidos, por el rostro del Dios viviente, que da vida y resucita a las victimas.

Estos eran los ideales ignacianos que movian a ese grupo. Los llevaron a la práctica con limitaciones, por supuesto, pero no tengo duda que esto es lo que los movia y de ello dieron insigne testimonio. $Y$ desde este espiritu de san Ignacio hay que entender cómo se comprendían ellos como jesuitas en el mundo de hoy. Jesuitas como ellos, y ciertamente ellos, son los que prepararon el cambio que se operó en la misión de la universal Compañia, cambio comparable al del Vaticano II y Medellín y por ello verdadero milagro y don de Dios. La misión actual de la Compañía quedó formulada como "servicio de la fe y promoción de la justicia" (CG XXXII, 1975), y todo ello llevado a cabo como "opción por los pobres" (CG XXXIII, 1983). Este cambio ha sido muy radical, ha significado para la Companía conversión, abandonar muchas cosas y muchos modos de proceder, perder las amistades de los poderosos y sus beneficios, y ganar el cariño de los pobres. Ha significado sobre todo volver al evangelio de Jesús, al Jesús del evangelio y a los pobres para quienes Jesús predicó y fue evangelio, buena noticia. Pero ha sido también un cambio muy importante y muy benéfico, especialmente para los paises del tercer mundo. Ha significado que la Compañía se haya hecho verdaderamente cristiana $y$ verdaderamente centroamericana, ha significado mantener la identidad de la Compañía de modo que la haga relevante en nuestro mundo y procurar una relevancia que la ayude a redescubrir su identidad ignaciana. $Y$ no es éste pequeño beneficio para la Compañía, producto en muy buena parte de jesuitas como los seis asesinados.

$\mathrm{Y}$ jesuitas como ellos son los que han verificado la verdad de lo que también dijo la CG XXXII: "No llevaremos a cabo la misión del servicio de la fe y de la promoción de la justicia sin pagar un precio." En los últimos catorce años desde que se dijeron estas palabras, muchos jesuitas han sido amenazados, perseguidos y encarcelados en el tercer mundo. El número de jesuitas asesinados creo que es alrededor de veinte, y de ellos, siete en El Salvador, el P. Rutilio Grande y ahora los seis de la UCA. Aunque sea trágico, hay que repetirlo: estas cruces son las que muestran que la elección hecha por la Compeñía ha sido correcta por ser cristiana y por ser actual, y las que muestran sobre todo que esa elección se ha llevado a la práctica. $\mathbf{Y}$, de nuevo, no es éste pequeño beneficio que los mártires hacen a la Compañía. 
Creo, pues, que fueron ignacianos y jesuitas tal como hoy los quiere la Compañía. Sin alharaces, sin palabras almibaradas y ain triunfalismos se sentían jesuitas, de nuevo más en las obras que en las palabras. Ciertamente eran de aquellos que se hacían las dos grandes preguntas de san Ignacio: "a dónde voy y a qué" e intentaban responderlas con honradez, sin el adorno de mucha palabrería espiritualista ni el disfraz de las prudencias diplomáticas y mundanas, ni siquiera con los discernimientos que a veces son paralizantes, pues, como antes he dicho, lo obvio no es objeto de discernimiento. Eran de los que buscaban la mayor gloria de Dios y recordaban aquello de san Ignacio "el bien, cuanto más universal, más divino." Y así comprendían su trabajo, sobre todo el trabajo específicamente universitario dirigido hacia las estructuras del pars y su transformación: para que la salvación llegara a más gente. Eran de los que estaban en la avanzada, en las trincheras, alli donde se juegan las soluciones a los problemas más graves de nuestro tiempo, y alli donde se escucha también más de cerca el fragor de la batalla. Si cayeron en la betalla, es porque estaban en ella.

Así es como los recuerdo, como seres humanos honrados con la realidad, como creyentes en Dios y seguidores de Jesús, y como jesuitas cabales de finales de este siglo $\mathrm{XX}$ en un país del tercer mundo. Cierto es que tuvieron limitaciones y fallos, cada uno los suyos y como grupo. Duros y adustos a veces, hasta con apariencia de intransigentes algunas veces, aunque no por defender lo suyo, sino por luchar por lo que consideraban mejor para el país, la Iglesia y la Compañía. Pero eso no les impidió vivir y trabajar unidos, llevando cada uno las cargas de los otros, y sintiéndose llevados también por el espíritu de los otros. De esta forma fueron compañeros de Jesús y realizaron la misión del cuerpo de la Compañía en el mundo de hoy.

\section{3. ¿Por qué los mataron?}

Después de esta breve semblanza espiritual de estos hermanos jesuitas, quisiera hacer algunas reflexiones sobre lo que ilustra su asesinato e ilumina su martirio. Un asesinato es oscurided, pero sub specie contrarii ilumina muchas cosas. Un martirio tiene luz propia y poderosa que dice más que mil palabras sobre las coses importantes de la vida y de la fe. Ofrezco, pues, estas reflexiones para que los vivos saquemos luz sobre la realidad en que vivimos y ánimo para transformarla.

La respuesta a la pregunta por qué los mataron sigue siendo sumamente importante porque de ella depende la comprensión de lo 
que estos jesuitas fueron e hicieron. Pero no s6lo eso; de la respuesta depende la comprensión de la realidad salvadoreña y la comprensión de nuestra fe, que - no lo olvidemos- comenz6 al pie de un crucificado, de un ajusticiado por los poderosos de este mundo. La respuesta es absolutamente sencilla y por ello mismo aterradora. "Se mata a quien estorba," decía Monseñor Romero. Y realmente estos jesuitas estorbaban mucho; no de otra forma pueden explicarse tantos ataques verbales y fisicos que antes he enumerado.

¿Y qué es lo que estorbaba de estos hombres? Sus adversarios y sus asesinos solian decir de forma ideologizada, y falsa, varias cosas contra ellos. Se los tenía por comunistas y marxistas; a veces se los llamaba antipatriotas; algunas veces hasta los llamaban ateos. $Y$ en el c olmo de la alucinación los acusaben de "liberacionistas." Irónica y trágica tergiversación ésta de usar un término evangélico central -"liberación"- para denigrar y descalificar a un creyente. En realidad, nada concreto querían decir con estas acusaciones, sino solo expresar su total rechazo hacia ellos y su deseo vehemente de verlos silenciados, fuera del pars, desaparecidos o muertos. Y recuérdese que en el pars también Pablo VI fue acusado de "comunista" cuando publicó la Populorum Progressio.

Otros, en la situación actual del país, formulaban acusaciones más concretas: apoyan al FMLN, son su "fachada" ideológica, son los responsables de la violencia y de la guerra, etc., dando por supuesto que el FMLN es el peor de los males del pars y que quien los apoya es automáticamente reo de muerte. Claro que, para la ultraderecha, "fachada" del FMLN es cualquiera que defienda a los pobres y diga la verdad sobre la violación de los derechos humanos: desde los sindicalistas que luchan por sus derechos y los comités de madres de asesinados y desaparecidos, hasta los beneméritos internacionalistas -esos hombres y mujeres que han dejado paz y comodidad en sus países para servir a los pobres en El Salvadorhasta Monseñor Rivera y Monseñor Rosa y la Oficina de Tutela Legal del Arzobispado.

Lo primero es simplemente falso. Estos jesuitas fueron seres humanos honrados y cristianos creyentes, convencidos que Jesús ha trardo la exigencia y los caminos de liberación, de liberación total, utópica. Por supuesto eran conocedores del marxismo, de sus importantes aportes para analizar la situación de opresión en el tercer mundo y de sus serias limitaciones; pero no fue en absoluto el marxismo su principal fuente de inspiración académica -Ellacuría era un eminente y creativo discipulo de Zubiri- ni su ideologia última para transformar la sociedad ni, mucho menos, lo que inspiró 
sus vidas personales. Eso lo fue el evangelio de Jesús, y desde él buscaron cómo encontrar los mejores conocimientos científicos, cómo juzgar y usar las diversas ideologías en favor de los pobres.

Tampoco es verdad lo segundo, aunque esto hay que explicarlo un poco más en detalle para que se conozca la verdad de lo ocurrido y para que no llegue a decirse $\longrightarrow$ a murmurarse en voz baja, pues casi nadie se atreve ahora a decirlo en voz alta- que, aunque trágico, ellos se buscaron su muerte. (En estos años se han dicho cosas como éstas, cuando ha sido asesinado algún sacerdote). Por sencillo que parezca el decirlo, lo que estos jesuitas apoyaban decididamente y hacia lo que eran realmente parciales eran las mayorías populares, y nada más. Infinidad de veces repetían que lo suyo no era apoyar un partido polftico o un gobierno concreto ni siquiera un movimiento popular determinado, sino juzgarlos a todos ellos y apoyar todo aquello que ayudara a hacer justicia al pueblo. También en esto eran fieles a las palabras y al espíritu de Monseñor Romero: "hay que juzgar de los procesos políticos según vayan o no en beneficio del pueblo." Por eso analizaban y apoyaban lo que de positivo y justo se expresaba en los movimientos populares $y$ también en el FMLN, pero criticaban lo que les parecía políticamente errado, sobre todo las tendencias puramente militaristas que abandonaban lo social y popular, y lo éticamente condenable, sobre todo algunas acciones terroristas y asesinatos de civiles. Nadie que haya leído las publicaciones de la UCA podrá ponerlo en duda.

Por lo que toca al conflicto y la guerra, recuerdo bien que en febrero de 1981, después de la primera gran ofensiva fallida del FMLN, Ellacuría dijo, ya entonces, que la solución para el país estaba en la negociación, palabras que entonces sonaban a traición para la derecha y no muy agradables para la izquierda; y ese mismo año, en el mes de mayo, la revista $E C A$ dedicó un número monográfico al diálogo y a la negociación. Aunque no eran, como tampoco lo fue Monseñor Romero, pacifistas a ultranza, aunque entendían y analizaban las causas de la guerra, su trágica inevitabilidad $e$ incluso su posible legitimidad a finales de los años setenta, no eran belicistas, consideraban la guerra como un grandísimo mal que debía desaparecer. No que esto los llevase a ignorar los bienes que también el FMLN ha trádo al pais -palabras impronunciables para la extrema derecha-, ni la creatividad, la heroicidad, el amor incluso de muchos de sus combatientes, pero tampoco los llevó a cegarse, antes al contrario, hacia los males de la guerra, ni nunca se dejaron llevar ni en la teoría - ni en la práctica por supuesto- por lo que Monseñor Romero condenó como mística 
de la violencia. En lenguaje político, pero con gran pathos humano y ético, Ellacuría solía decir lapidariamente: "el camino de la guerra ya ha dado todo lo que podía dar de sí, hay que buscar el camino de la paz."

Por ello apoyaron decididamente el dílogo-negociación, lo cual fue muy claro en los últimos anos y sobre todo en los últimos meses. La universidad hizo todo lo posible para facilitar el diálogo, hablando con unos y con otros. Y eso lo sabe bien el presidente Cristiani, con quien algunos de ellos hablaron unas pocas veces en privado, y a quien invitaron a la UCA, el 19 de septiembre de este año, cuando la universidad otorgó un doctorado honoris causa al presidente de Costa Rica Oscar Arias por su trabajo por la paz. Para facilitar el diślogo hablaban con los dirigentes del FMLN, con algunos miembros del gobiemo, con toda clase de políticos y diplomáticos, incluso con algunos militares, pero todo lo hacian con la única finalidad de apoyar una solución negociada, más humana y más cristiana al conflicto. Hubo, pues, conocimiento, contactos, apoyo a lo positivo y críticas a lo negativo del FMLN. Hubo también diálogo con algunas fuerzes gubernamentales, incluso apoyo a todo lo que ofreciese un poco de luz al callejón sin salida del país, proviniese del gobierno, de los partidos políticos o de la embajada norteamericana, aunque obviamente, se mantuvieron firmes en la denuncia de los abusos y violaciones de los derechos humanos cometidas por la Fuerza Armada y los escuadrones de la muerte, en afirmar la responsabilidad del gobiemo en ello, en denunciar la impunidad de los crfmenes y la inutilidad de la administración de justicia, en desenmascarar la dependencia de Estados Unidos. No fueron, pues, fachada del FMLN ni de ningún otro grupo o proyecto político, aunque los analizaron todos y promovieron lo bueno, mucho o poco, que vieron en ellos. Si de algo quisieron ser "fachada" estos jesuitas fue de las mayorías populares, de los pobres y oprimidos del país. Y ésta es la tragedia- por eso, en último término, los mataron.

$\mathrm{Si}$ he recordado estas cosas, bien conocidas en El Salvador, es para recalcar que la razón profunda de su muerte no está en las acusaciones que lanzaron contra ellos. Como en el caso de Monseñor Romero, de muchos otros mártires y de Jesús de Nazaret, la razón más sencilla y más profunda está en otra parte. Quisiera decir que quienes los mataron habrán aducido para si razones falsas, si es que se puede hablar de "razones" para tan abominable crimen, y éticamente injustificables, por supuesto. Pero en lo fundamental no se equivocaron, como no fue equivocación - a pesar de lo que dice Bultmann- el ajusticiamiento de Jesús de Nazaret. No había 
razones justas para eliminarlos, pero era necesario hacerlo. Y esta necesidad -trágicamente- es estructural y no proviene de la crueldad de tal o cual persona, de tal o cual grupo. Es la necesaria reacción de los ídolos de muerte hacia cualquiera que se atreve a tocarlos.

Que existen ídolos en este mundo es convicción profunda en América Latina. De ello habló Puebla y, con mayor profundidad, Monseñor Romero en su última carta pastoral de 1979, ayudado por cierto por Ignacio Ellacuria. Y lo ha teorizado teológicamente, cosa que no se hace en otros lugares, la teología de la liberación. Como tantas veces se ha dicho, pero hay que repetirlo porque sigue siendo una espantosa realidad, los fdolos son realidades históricas, realmente existentes, que se hacen pasar por divinidades, mostrándose con las características de la divinidad: ultimidad, autojustificación, intocabilidad, ofreciendo salvación a sus adoradores, aunque los deshumanizan, y, sobre todo, exigiendo víctimas para subsistir. Esas realidades históricas son lo que llamamos los ídolos de muerte, que en El Salvador fueron concretados por Monseñor Romero como el idolo de la riqueza, la absolutización del capital -el primer y más grave de los fdolos y el originante de todos los demás-y la doctrina de la seguridad nacional; a lo cual añadió la seria advertencia a las organizaciones populares para que no se convirtieran en fdolos ni hiciesen nunca de la violencia, aun en el caso que llegase a ser legítima, una mística. Existen ídolos, pues, y, como lo dijo Monseñor Romero gráficamente, no se puede tocar a los idolos impunemente: " Ay de aquel que toca la riqueza. Es como un cable de alta tensión. Se quema!" Eso es lo que ocurrió con los seis jesuitas, y con tantos otros.

Los jesuitas de la UCA tocaron el ídolo al decir la verdad de la realidad, analizar sus causas y proponer las mejores soluciones. $\mathbf{Y}$ esto que parece cosa tan buena, tan beneficiosa, que debiera ser alabada y apoyada por todos, eso es perseguido por los idolos. Los jesuitas, ante todo, dijeron la verdad del pars en sus publicaciones y declaraciones públicas. Dijeron que el hecho más grave es la masiva, cruel e injusta pobreza de las mayorias, que cuando estas mayorias se organizan - con todo derecho y justicia - simplemente para poder vivir son reprimidas, todo lo cual sigue siendo verdad en el país, aunque no lo quieran reconocer eficazmente ni las políticas gubernamentales ni las de Estados Unidos. Asimismo ni estas políticas no están dirigidas por esa realidad fundamental ni para ponerle solución. 
Pero además de esta denuncia profética fundamental, analizaron la realidad y sus causes como corresponde a una institución universitaria. En 1971 la UCA publicó un libro sobre una famosa huelga de maestros, dándoles la razón - lo cual le costó ya entonces la pérdida del subsidio gubernamental-, y empezó a exigir una reforma agraria como la solución más radical y necesaria para los males del país. $Y$ desde entonces sus enemigos se dieron cuenta que estaban tocando el ídolo. En 1972, la UCA publicó otro importante libro mostrando, denunciendo y analizando el fraude electoral de las elecciones presidenciales - de lo cual se seguirían graves males, pues el pueblo empezó a desconfiar para siempre de que la solución a la injusticia pudiera provenir sólo de las elecciones. En 1976, por recordar otro momento importante, la revista $E C A$, cuando el presidente Molina echó marcha atrús en la incipiente y mínima reforma agraria, publicó un editorial de Ignacio Ellacurfa, "A sus órdenes mi capital." Y desde entonces su palabra de verdad y sus análisis objetivos se hicieron siempre presentes en la realidad salvadorefia: la verdad sobre la pobreza, el desempleo, la espantosa falta de vivienda, de educación y salud, la verdad sobre la represión y la violación de los derechos humanos, la verdad sobre la marcha de la guerra, la verdad sobre la dependencia de Estados Unidos, la verdad también sobre el accionar del FMLN y de los movimientos populares, sus acciones y estrategias, correctas o equivocadas... y tantas otras verdades. Como otra expresión de esa voluntad de verdad, la UCA comenzo hace dos años un instituto de opinión pública, dirigido por el P. Martín-Baró, que muy pronto se convirtí́ en el medio más objetivo para saber qué pensaben los salvadoreños.

La verdad, expuesta universitariamente, es lo que intentaron decir y analizar estos jesuitas, con la mayor objetividad posible, como ha sido reconocido por innumerables instituciones internacionales, por muchísimos políticos, embajadores, analistas y periodistas que desfilaban por la UCA para conocer de boca de esos hombres la verdad del país. No todos estaban siempre de acuerdo con todos sus análisis, pero todos - con excepción de la muy extrema derechareconocían su voluntad de verdad y sus logros importantes en analizar la verdad. No fueron, pues, voceros de ningún grupo o institución, sino voceros de la misma realidad. Y si alguna parcialidad tuvieron y reconocieron es la de ver la verdad desde los pobres. Y si pronunciaban la verdad tan decididamente es porque estaban convencidos que al menos la verdad está a favor de los pobres - que, a veces, es casi lo único que tienen a su favor.

Decir la verdad, comunicarla universitariamente -como en el 
caso de estos jesuitas - o pastoralmente -como en el caso de Monsefior Romero- siempre ha sido peligroso porque los ídolos buscan ocultar su verdadera realidad de muerte $y$, por necesidad, generan mentira para ocultarse. El pecado siempre busca su propio ocultamiento y el escándalo su propio encubrimiento. Decir la verdad se convierte entonces en desenmascarar la mentira, y eso no se perdona. El pecado del mundo, las estructuras de injusticia que dan muerte, no son solo injustas, sino que tratan de ocultar su maldad e incluso hacerse pasar por cosas buenas, revestirse del bien, encubriendo muchas veces la realidad con el lenguaje de eufemismos: "libertad de expresión," "democracia," "elecciones," "defensa del mundo occidental, democrático y cristiano." $Y$ es que el mundo de la injusticia y del poder, que da muerte a los pobres, lleva a cabo un gigentesco encubrimiento para ocultar el escándalo de las víctimas que produce, en comparación con el cual los conocidos encubrimiento del Watergate o del Irangate son faltas pequeñas o pecados veniales.

Decir la verdad, entonces, no es s6lo disipar la ignorancia, lo sino combatir la mentira, lo cual es esencial para una universidad y es central en nuestra fe. Si algo he aprendido en estos años en El Salvador es que el mundo en que vivimos es simultáneamente un mundo de muerte y un mundo de mentira, y lo he redescubierto en la Escritura. Como dice Juan, el maligno es a la vez asesino y mentiroso. Como dice Pablo, el mundo aprisiona la verdad con la injusticia. Estos jesuitas quisieron liberar la verdad de la esclavitud a la cual la someten los opresores, poner luz en medio de la mentira, poner justicia en medio de la opresión, poner esperanza en medio del desconsuelo y poner amor en medio de la indiferencia, la represión y el odio. Y por eso los mataron.

La verdad que dijeron estaba iluminada por el conocimiento que se producia en la universidad, lo más racional y objetivo posible; pero estaba iluminada también y esencialmente por los pobres. Aceptaban la escandalosa afirmación del profeta Isajas: el pueblo crucificado, desfigurado y sin rostro, el siervo doliente de Jahvé, ha sido puesto por Dios como luz de las naciones. Esta es, para quienes buscan la verdad, la opción por los pobres. Esta opción no es sólo una opción categorial, exigida por la Iglesia y la Compañía sólo a los que hacen trabajo pastoral, sino que es una opción totalizante que afecta a todo hombre y a todo creyente, en todas sus dimensiones: en lo que sabe, en lo que espera, en lo que hace y en lo que celebra. Es una opción totalizante para la Iglesia y para la universidad. Y esa opción es la que hicieron estos jesuitas, también como universitarios. Estos jesuitas creyeron $-y$ la experiencia lo confirma- que se ve 
más desde abajo que desde arriba, que se conoce mejor la realidad desde el sufrimiento y la impotencia de los pobres que desde el dominio de los poderosos. Su verdad fue, pues, posibilitada por los pobres.

La opción, sin embargo, incluye también esencialmente devolver a los pobres su verdad, y así la verdad que iba generando la universidad la devolvieron a los pobres, pare defenderlos, iluminarlos y animarlos. La UCA hizo una opción por los pobres y la puso en práctica de diversas maneras. En la docencia se pretendía comunicar ante todo lo que es la realidad nacional -esa era la gran materia a enseñar, la materia más obligatoria en todos los cursos, y la que debía estar presente en cualquiera de ellos-, para que de este modo la realidad de las mayorías populares - la verdadera realidad nacional y no las excepciones o las anécdotas de la realidad que suelen enseñarse a veces en las universidades- con su sufrimiento y también con su esperanza y su creatividad tomara la palabra.

La pregunta que dirigía cualquier investigación era la de descubrir a fondo la realidad oprimida y sus causas, y ofrecer positivamente las mejores soluciones. Este era un gran ideal, dificil de conseguir, pero en el que estos jesuitas pusieron gran empeño: se trataba de ofrecer modelos, con posibilidades reales, de una economía, una política, una tecnología para la vivienda, la educación, la salud, una educación, una creatividad artística y cultural, una religiosidad cristiana y liberadora que hiciera posible la vida de diez millones de seres humanos a finales de este siglo en este pobre y pequeño país de El Salvador. A esto estaba dirigida la investigación.

En la proyección social, la UCA se abría directa e inmediatamente a las mayorías populares, a través de sus publicaciones, de sus tomas de postura, valientes, numerosas y públicas, a través del Instituto de Derechos Humanos, dirigido por el P. Montes, a través del Centro Universitario de Documentación e Información y del Centro Monseñor Romero en cosas teológicas, pastorales y religiosas. Con ello querían ayudar a generar una conciencia colectiva en el país, crítica y constructiva, que ayudase a los pobres. Hacia los movimientos populares estos jesuitas fueron muy abiertos y los apoyaron decididamente por lo que tenían de populares, aunque no por ser uno u otro movimiento. Teórica y prácticamente procuraron exponer la necesidad, la justicia, la identidad y la finalidad de los movimientos populares. Y gráficamente se podía ver esto en el mismo recinto de la universidad que nunca cerró sus puertas a sindicalistas, marginados, madres de desaparecidos, grupos de derechos humanos, agentes populares de pastoral, etc. 
Una verdad pronunciada, enalizada y presentada de forma universitaria y cristiana; una universidad asf, es lo que no toleran los fdolos. A estos jesuitas universitarios los mataron por hacer de la universidad un instrumento eficaz para defender a las mayorfas populares, por convertirse en conciencia critica en una sociedad de pecado $y$ en conciencia creativa de una futura sociedad distinta, la utopía del reino de Dios en favor de los pobres. Los mataron por intentar hacer una universidad verdaderamente criatiana. Los mataron porque creyeron en el Dios de los pobres y pusieron a producir esa fe a través de la univeraidad.

\section{4. ¿Quiénes los mataron?}

Siempre surge esa pregunta cuando hay asesinatos notorios. Monseñor Rivera ha afirmado que existe una vehemente presunción de que fue la Fuerza Armada o los escuadrones de la muerte relacionados con ella. El informe de la Oficina Tutela Legal del Arzobispado, del 28 de noviembre, concluye después de 38 páginas de ań́lisis que "todas las evidencias e indicios en su totalidad y correlación, eatablecen que los responsables del asesinato de los seis sacerdotes jesuitas $y$ de las dos empleadas de servicio fueron elementos pertenecientes a la Fuerza Armada." Es difícil explicar, en efecto, que en una zona totalmente vigilada $y$ controlada por soldados-quienes ya habían registrado la casa dos días antes y preguntado qué jesuitas vivian en ella-, a las dos y media de la madrugada, en estado de sitio y bajo ley marcial, un número grande de personas, unas 30 , pudiesen con toda impunidad entrar en la casa, permanecer en ella durante largo tiempo, asesinar a ocho personas y destruir parte de las instalaciones del edificio, usendo luces, produciendo grandes ruidos y ocasionando un visible incendio, sin ser perturbados por los soldados de los alrededores inmediatos y saliendo después con toda tranquilidad. Además, testigos presenciales afirman haber visto a esos 30 hombres vestidos de militar. De hecho -irónica y trágicamente- los jesuitas se quedaron a dormir en la casa -aun con el temor, razonable en base a la experiencia, de que les pusiesen alguna bomba- precisamente porque la zona estaba rodeada por numerosos soldados y les parecía impensable que en esas circunstancias alguien se atreviese a algún ataque físico a la casa, pues la conclusión sobre quiénes eran los responsables sería obvia.

Lo que aquí nos interesa recalcar, sin embargo, no es tanto quiénes fueron los autores materiales del asesinato, sino quiénes son los verdaderos autores, aquellos que fomentan el antirreino y no 
quieren que el reino de Dios, la justicia, la fraternidad, la paz, la verdad y la dignidad, sean una realidad en El Salvador. Es todo un mundo de pecado el que una vez más ha dado muerte a gente inocente y a gente que ha trabajado por los pobres. Cuando preguntaron a Monseñor Rivera por los autores del asesinato su respuesta fue muy certera: "son los que asesinaron a Monseñor Romero y a quienes no les basta 70,000 asesinatos."

Esa es la verdad más profunda y más cuestionante. Son los ídolos, los poderes de este mundo, los que no quieren que en verdad algo importante cambie en el pais, aunque tengan que aceptar, forzados por la situación, pequeños maquillajes. Este asesinato, muestra que los ídolos siguen produciendo acciones bárbaras e impensables y pueden seguir actuando con total impunidad, muestra que en el país puede haber habido algunos cambios en los últimos años, pero que los cambios se frenan cuando llegan a tocar a los ídolos. Estos toleran elecciones, y en siete años ha habido cinco elecciones, dos para presidente y tres para la asamblea, toleran algunas leyes reformistas, paulatinamente suavizadas, toleran presiones de Estados Unidos para controlar a los escuadrones de la muerte, toleran los millones de dólares que Estados Unidos ha dado para mejorar - es decir, para que empiece a funcionar- la administración de la justicia, toleran que la inmensa ayuda militar y económica esté condicionada, según dicen a que mejoren los derechos humanos... Pero todo ha sido en vano. Los idolos siguen recalcitrantes y actuantes, y producen acciones más feroces. Por ello hay que entender bien quiénes realmente han dado muerte a estos jesuitas y a tantos otros miles, sin confundir a los autores materiales de tan horrendo crimen con la realidad activamente idolátrica de El Salvador. A los asesinos materiales, estos jesuitas, como Monseñor Romero, los han perdonado pues "no saben lo que hacen;" pero a los idolos nunca los perdonaron, sino que vivieron y lucharon por su erradicación.

Si recalco este punto es por varias razones importantes. La primera y fundamental es que la verdadera responsabilidad de estos asesinatos no hay que concentrarla en los 30 hombres vestidos de militar que perpetraron el crimen y destruyeron parte del Centro Monseñor Romero. Hay una "analogía" en la responsabilidad, y aunque esto sea conocido hay que recordarlo. Responsables son, por supuesto, los que idearon y llevaron a cabo el crimen. Pero responsables son también, más o menos, por acción u omisión, muchos otros. Los que en El Salvador producen represión para que no llegue a haber justicia en el país, participan de la responsabilidad. En 
Estados Unidos innumerables personas acusan hoy, con razón, a su gobierno por propiciar una política incapaz de detener la represión. Pero no basta con afirmar estas coses. ¿Qué han hecho tantos gobiernos en Europa y en el resto del primer mundo, tan democráticos ellos, para parar efectivamente la barbarie que ha asolado a El Salvador en los últimos quince afios? ¿Qué palabra eficaz han pronunciado los líderes religiosos, las conferencias episcopales, las universidades de parses democráticos y cristianos? ¿Que han hecho los medios de comunicacion del mundo occidental durante estos años, cuando día a día morían seres humanos a causa de la pobreza y de la represión? Por acción y, sobre todo, por omisión, muchos seres humanos han ignorado, callado, cuando no tergiversado, la tragedia salvadoreña. Comprendo que para los ciudadanos del primer mundo sea dificil captar la hondura de esta tragedia, pues para los que dan la vida y la libertad por supuestas es difícil comprender lo que significa pobreza y represión en los parses del tercer mundo, y por eso tienden a ignorarla, a desentenderse de ella y a callar. Pero quizás callan también por un inconsciente sentimiento de culpobilidad: no se puede seguir viviendo en la abundancia, teniéndolo prácticamente todo y deseando tener cada vez más, cuando muchos millones de seres humanos están cada día muriendo de hambre. Todo este conjunto de acciones y de omisiones es lo que da muerte a los pobres y a quienes los defienden. Por ello, la pregunta por los asesinos es una pregunta que se dirige a todos nosotros.

Soy muy consciente, y estoy entrañablemente agradecido, por la existencia de muchas personas, comunidades y grupos en todo el mundo que se han mostrado solidarios con El Salvador, y entre ellos hay sacerdotes, religiosas, algunos obispos, algunos periodistas, políticos y universitarios, muchas instituciones de derechos humanos y muchos hombres y mujeres, cristianos o simplemente honrados, que han dado lo mejor de sf mismos, sus capacidades, su tiempo, sus bienes, su vida incluso, por los pobres de El Salvador. Ahora, una vez más, muchos de ellos han sido expulsados o forzados a abandonar el pais. Como símbolo de todos ellos quisiera recordar a las cuatro misioneras norteamericanas que dieron su vida en 1980 , el don más precioso de Estados Unidos a El Salvador. Para ellos, la eterna gratitud del pueblo salvadoreño. Pero para los otros, para los que no se interesan por los pobres de este mundo, sino que solo piensan en sus propios intereses, "los intereses nacionales" -como dicen los gobemantes- o simplemente "el vivir mejor" que buscan los ciudadanos, sin quedarse aterrorizados ante el abismo, en 
aumento, entre los países ricos y los pobres, ante la relación causal que existe entre la abundancia de unos y la miseria de otros, la libertad de unos y la represión de otros, estos asesinatos tienen que ser una seria llamada de atención, una llamada a la conversión. Para los cristianos, es la exigencia ineludible a ponernos todos delante de ese crucifijo que son los pueblos crucificados y preguntamos qué hemos hecho y qué vamos a hacer por Cristo.

Una segunda reflexión es que estos asesinatos de sacerdotes y jesuitas han ocurrido en el mundo occidental, democrático y cristiano, como gusta llamarse, y que invoca a Dios; más aún, que dice invocar al verdadero Dios $y$, por ello, lo defiende de los marxistas y ateos. No hay que olvidar que es América Latina, un continente occidental y cristiano, el continente donde ha habido, con gran diferencia, más mártires cristianos desde el Concilio Vaticano II. Pasan de mil los obispos, sacerdotes y religiosas que de una u otra forma han sido amenazados, encarcelados, expulsados, torturados y asesinados. $Y$ son decenas de miles los cristianos asesinados por predicar la verdadera palabra de Dios, por poseer una Biblia o los documentos de Medellín y ponerlos en práctica. Ante esto, no puede uno menos de preguntarse cuál hubiese sido la reacción del mundo occidental y cristiano si estas cosas hubiesen sucedido en países comunistas, en Hungría o en Polonia, cuál hubiera sido el clamor y la indignación en el congreso de Estados Unidos o en el parlamento inglés, qué no se hubiera dicho en las conferencias episcopales y en el Vaticano. Pero las reacciones del mundo occidental "oficial" han sido muy suaves en comparación con la tragedia. $Y$ es que no quiere reconocerse que el mundo no puede dividirse simplemente entre buenos y malos, cristianos y demócratas unos, comunistas y ateos otros. No quiere reconocerse que la línea divisoria de la humanidad es la idolatría, que está presente por doquier, entre los llamados comunistas y los llamados demócratas, entre los llamados no creyentes y los llamados creyentes.

Lo menos que debiera provocar el asesinato de estos seis jesuitas es la honrada pregunta que el mundo occidental y cristiano debe hacerse a sí mismo, preguntarse si es tan bueno y santo, como dicen, tan humano y libre como proclaman. Debiera desenmascarar el manto de hipocresía con que se quiere encubrir una democracia y una libertad para pocos a costa de la represión y pobreza para muchos. Debiera hacer sospechar al menos que la riqueza, la seguridad nacional, la libertad individual de unos pocos generan por necesidad idolos que producen muchas víctimas en otros lugares, aunque sea a miles de kilómetros de distancia. Los jesuitas ase- 
sinados insistieron en esto hasta el final de sus días, y recuerdo que hace muy poco tiempo comentábamos con Ellacuría la absoluta verdad de las sencillas palabras de la Escritura: "la raíz de todos los males es la ambición del dinero." Todos aquellos que buscan acumular dinero y sólo piensan en vivir todavía mejor debieran mirarse en el espejo de las víctimas de este mundo para ver sin tapujos los males que generan.

Una tercera reflexión es sobre la investigación que se exige cuando ocurren asesinatos notorios. Es natural que la exijan los cercanos a las víctimas, y es comprensible que, en algunos casos, la exijan aquellos para quienes estos asesinatos significan un costo político muy alto, el gobierno de El Salvador y el de Estados Unidos en este caso. Pero hay que estar claros en lo que significa en El Salvador exigir y prometer una investigación exhaustiva. Setenta mil son los asesinados y sólo se ha aclarado -aunque superficialmente- el de las cuatro religiosas norteamericanas y quiź́s alguno más. El caso de Rutilio Grande, a pesar de las promesas del entonces presidente Molina, sigue sin aclararse. El caso de los cinco dirigentes del Frente Democrático Revolucionario, sacados violentamente del colegio de los jesuitas y perpetrado a plena luz del día, sigue sin aclararse. El caso de Monseñor Romero, a pesar que tanto se ha investigado, sigue clamorosamente sin aclaración. $Y$ si esto ocurre en los casos notorios, puede comprenderse lo que ocurre cuando se asesina a desconocidos campesinos, miles de ellos, a veces masivamente como en El Mozote, el Sumpul... Y eso que muchas instituciones de derechos humanos no sólo denuncian los asesinatos, sino que dan importantes pistas sobre los responsables. Eso lo hacen en El Salvador varias instituciones de derechos humanos, entre ellas, con admirable objetividad, la Oficina de Tutela Legal del Arzobispado, y el Instituto de Derechos Humanos de la UCA. Lo hacen instituciones intemacionales, Amnistía Internacional en Londres, America's Watch en Nueva York, CODEHUCA en San José de Costa Rica. Lo ha hecho durante varios años el enviado especial de las Naciones Unidas, Pastor Ridruejo, quien, en su último informe de hace pocos días, ha afirmado el empeoramiento de los derechos humanos y el aumento de la tortura en El Salvador. En casos especiales, por ser extranjeros los asesinados, como en el caso del asesinato del suizo Jürg Weiss y de la médico francesa Madeleine ha habido serias investigaciones hechas por representantes de sus respectivos países y han dado más que suficiente información para hallar a los responsables. Sin embergo, con tan abundante información, con indicios y pistas tan serias, la administración de 
justicia en El Salvador ha hecho muy poco con seriedad. Más aún, cuando la primera junta de gobiemo, en 1979, nombró una comisión especial investigadora, ésta dimitió en pleno a las pocas semanas, cuando llegó al poder la segunda junta de militares y demócrata cristianos por la incapacidad para poder hacer algo serio y la fundada sospecha que los responsables nunca serían juzgados. Algunos de sus miembros, por cierto, tuvieron que salir del país. Y en otras ocasiones, los abogados o jueces que llevaban casos importantes, fueron también amenazados y tuvieron que abandonarlos.

¿Para qué sirve, pues, la anunciada investigación del asesinato de los jesuitas? Hasta ahora las investigaciones han servido para muy poco. Ojalá se investigue y se aclare este caso y los otros 70,000, por supuesto. Pero ojalá los que ahora prometen una investigación para dar la sensación de normalidad y de democracia investiguen antes por qué no ha habido ni ha podido haber en El Salvador investigaciones serias. $\mathrm{Y}$ ojalá investiguen por qué la inmensa mayoría de las victimas de crimenes notorios - $y$, por supuesto, los de la gente sencilla- resultan ser personas dedicadas a defender a los pobres.

Personalmente me ha llegado a producir hastio hasta la misma palabra "investigacion." En nuestra comunidad, cuando los sucesivos gobiernos anunciaban que se llevaria a cabo "una investigación exhaustiva" ante un crimen notorio, solíamos comentar irónicamente que bestaría con una investigación sencilla, normal y corriente, pues las investigaciones "exhaustivas" nunca terminan. Ojalá las promesas de investigación no se conviertan en elegante excusa, precisamente, para no detener la represión. Y ojalá la investigación de este caso, si es que se lleva a cabo hasta el final y se juzga a los responsables, no sea un encubrimiento para distraer la atención de los 70,000 casos que deben ser investigados, y no sea en el colmo del sarcasmo- una excusa para decir que las cosas van mejorando en El Salvador.

La palabra "investigacion" ha corrido el mismo destino que otras nobles palabras: "democracia," "elecciones"... dicen poco o nada, y se usan muchas veces para encubrir lo contrario de lo que significan. Personalmente pienso a veces que es mejor que no haya una investigación, que quede para la historia que quien asesinó a Monseñor Romero y a miles de cristianos fue el pecado del mundo, el entirreino, los ídolos. Pues mucho más importante es repetir y proclamar esa gran verdad que llegar a saber un día quién fue el asesino material. Y es importante impedir que los ídolos y quienes los apoyan puedan llegar a tranquilizar su conciencia porque, al fin 
y al cabo, ya se conoce quién apretó el gatillo.

La cuarta reflexión es obligada. Si se puede matar con tal impunidad a estos jesuitas, conocidos y respetados, personajes internacionales algunos de ellos, pudiendo prever -como está ocurriendo - las reacciones mundiales, los altos costos políticos, las presiones internacionales, si nada de esto pudo poner freno a la barbarie de asesinar a seis sacerdotes, podrá fácilmente comprenderse cúál es la defensa que tendrán los campesinos perdidos en pueblecitos y cantones: prácticamente ninguna. Aunque sea obvio, hay que repetirlo. ¿Quién en el mundo trabaja realmente para frenar y pedir una investigación de las masacres de El Mozote y del Sumpul o de la más reciente, el día 31 de octubre de este affo, de los diez sindicalistas asesinados en plene luz del día? Esta vez se conocen los nombres de dos sencillas mujeres del pueblo, Julia Elba y Celina, y también se investigarán sus muertes junto con las de los jesuitas. Pero muchísimos más nombres permanecen en el anonimato y sus muertes sin investigación. Como dijo el Señor Jesús, si estas cosas se hacen con el leño verde, qué no se hará con el lefio seco.

Mi última reflexión es algo que me ha venido a la mente con frecuencia al pensar en el caso de Monseñor Romero. Por supuesto que esclarecer su caso es importante para el país si ello muestra voluntad de verdad y significa un freno para futuros posibles asesinatos. Pero muchas veces tengo la sensación que investigar su caso y ahora, el de los jesuitas, no es más que dar vueltas alrededor de cadáveres sin el más mínimo interés por lo que los asesinados fueron en vida y por la herencia que nos han legado. Los gobiernos de El Salvador y de Estados Unidos hablan ahora de investigar el caso de los seis jesuitas. Ojalá lo hagan. Pero ¿no es mucho más importante para el pais recordar lo que hicieron en vida, mantener presente su espiritu?

Los pobres de El Salvador lloran a sus muertos, pero quieren sobre todo que siga vivo aquello por lo que dieron su vida. Si se nos permite soñar, ¿no será más importante mantener vivos a estos mártires que esclarecer sus cadáveres? ¿No es mucho más necesario para el país mantener la verdad, la misericordia, la justicia, la dignidad por la que vivieron que saber los nombres de sus asesinos? Lo segundo no es nada fácil, como sabemos, pero lo primero es mucho más difícil, y más necesario. Ojalá, soñemos, algún día el gobierno salvadoreño, el gobierno y el congreso norteamericano, pongan a producir lo que fueron en vida estos mártires, estudien en serio lo que estos hombres proponían como solución para el país, 
reconozcan la verdad tal como ellos la analizaron, reconozcan que sin justicia y sin respeto a los derechos humanos no habrá solución con o sin elecciones-. Estos mártires no quieren venganza, ni siquiera están interesados en que se les haga justicia a ellos. Lo que quieren es que la paz y la justicia lleguen a El Salvador y que se recorran los mejores caminos que ellos nos dejaron para alcanzarlas.

Estas son las reflexiones que se me ocurren a propósito de los asesinos de mis hermanos jesuitas. Importante es saber quiénes los mataron, pero más importante es saber por qué se puede asesinar tan impunemente, antes, durante y después de los hechos. Importante es investigar asesinatos del pasado, pero mucho más importante es frenar de una vez para siempre los asesinatos del futuro. Importante es aclarar los asesinatos notorios, pero más importante es esclarecer los asesinatos masivos de los campesinos que mueren anónimamente. Importante es que en muerte se haga justicia a mis hermanos jesuitas, pero mucho más importante es que se los mantenga presentes poniendo a producir lo que fueron e hicieron durante sus vidas.

\section{5. ¿Qué universidad nos dejan?}

La negrura de los asesinatos esclarece trágicamente cosas muy importantes: que hay ídolos en este mundo y producen victimas, que hay pecado y produce muerte. Pero cuando estos asesinatos son también martirios - miles ha habido en El Salvador- entonces iluminan lo más decisivo de nuestras vidas. Con la muerte se dice la verdad sobre la propia vida y con su muerte estos jesuitas han dicho la verdad sobre lo que fueron e hicieron, pero su muerte martirial confirma también que lo que fueron e hicieron fue verdad. Por ello, aunque pueda parecer una disgresión, quisiera mencionar ahora tres cosas importantes que quedan iluminadas por su martirio: lo que es una universidad de inspiración cristiana, una Iglesia de los pobres y una teología de la liberación. Lo hago porque son temas importantes, actuales y también debatidos, y por ello necesitan ser iluminados. $Y$ lo hago porque sobre estas cosas nos han dejado una importante herencia.

¿Qué universidad nos dejan? Ante todo nos dejan una nueva idea de universidad cristiana para nuestro tiempo - comparable en su empaque a la de John Henry Newman hace un siglo- y muchas realizaciones de esa nueva universidad de inspiración cristiana. Ya al hablar del por qué los mataron he dicho algunas cosas sobre lo que para ellos era la UCA, idealmente, por supuesto, pero también en muchas de sus realizaciones. Dicho ahora en una palabra, nos 
dejan el que el saber universitario y cristiano tiene que ser puesto y puede ser puesto al servicio de los pobres.

Sobre esa idea de una nueva universidad cristiana al servicio de los pobres escribieron muchas páginas. Y aunque en este escrito he evitado largas citas, permítaseme - para ser conciso- una excepción ofreciendo las palabras que pronuncio Ignacio Ellacurfa cuando recibí un doctorado honoris causa en la universided de Santa Clara, California, en 1982, sobre lo que es una universidad de inspiración cristiana.

El punto de arranque para nuestra concepción de lo que debe ser una universidad viene dado por una doble consideración. La primera y más evidente, que la universidad tiene que ver con la cultura, con el saber, con un determinado ejercicio de la racionalidad intelectual. La segunda, ya no tan evidente y común, que la universidad es una realidad social y una fuerza social, marcada históricamente por lo que es la sociedad en la que vive y destinada a iluminar y transformar, como fuerza social que es, esa realidad en la que vive y para la que debe vivir...

Nuestro análisis intelectual encuentra que nuestra realidad histórica, la realidad de El Salvador, la realidad del tercer mundo, es decir, la realidad de la mayor parte del mundo, la realidad histórica más universal, se caracteriza fundamentalmente por el predominio efectivo de la falsedad sobre la verdad, de la injusticia sobre la justicia, de la opresión sobre la libertad, de la indigencia sobre la abundancia, en definitiva del mal sobre el bien...

Inmersos en esa realidad, poseídos por ella, nos preguntamos qué hacer universitariamente. Y respondemos, ante todo, desde un planteamiento ético: transformarla, hacer lo posible para que el bien domine sobre el mal, la libertad sobre la opresión, la justicia sobre la injusticia, la verdad sobre la falsedad y el amor sobre el odio. Sin este compromiso y sin esta decisión no comprenderemos la validez de una universidad y, menos aún, la validez de una universidad de inspiración cristiana...

Una universidad de inspiración cristiana es aquella que enfoca toda su actividad universitaria... desde el horizonte iluminador de lo que significa una opción preferencial cristiana por los pobres... Le universidad debe encarnarse entre los pobres intelectualmente para ser ciencia de los que no tienen ciencia, la voz ilustrada de los que no tienen voz, el respaldo intelectual de los que en su realidad misma tienen la verdad y la razón, aunque sea a veces a 
modo de despojo, pero que no cuentan con las razones académicas que justifiquen y legitimen su verdad y su razón...

Nuestra universidad ha intentado modestamente ponerse en esta línea dificil y conflictiva. Ha obtenido algunos resultados a través de sus investigaciones, de sus publicaciones, de sus denuncias; a través sobre todo de unos hombres, que han dejado otras alternativas más brillantes, más mundenas y más lucrativas para entregarse vocacionalmente a la liberación universitaria del pueblo salvadoreño; a través en algunos casos de estudiantes y profesores, que han pagado muy dolorosamente con su propia vida, con el exilio, con el ostracismo, su entrega al servicio universitario de las mayorías oprimidas...

Por esta labor hemos sido duramente perseguidos... Si nuestra universidad nada hubiera sufrido en estos años de pasión y de muerte del pueblo salvadoreño, es que no habría cumplido con su misión universitaria y, menos aún, habria hecho visible su inspiración cristiana. En un mundo donde reina la falsedad, la injusticia, la represión, una universidad que luche por la verdad, por la justicia y por la libertad, no puede menos de verse perseguida.

Esta es en pocas y lúcidas palabras cómo pensaban esos hombres lo que es una universidad de inspiración cristiana en el tercer mundo. Y a ello llegaron no sólo por reflexión teórica, sino también por reflexión sobre la experiencia histórica de lo que es una universidad en el tercer mundo. Por ello eran muy conscientes tanto de las posibilidades como de la peligrosidad de una universidad para extender el reino de Dios. Quizás extrañe decirlo, pero eran muy conscientes de que también una universidad está amenazada de pecaminosidad, de que puede servir al antirreino, más en concreto, que puede reforzar a través de los profesionales que produce y a través de su peso social las estructuras injustes de una sociedad. $Y$ no sólo que la universidad pueda ser todo eso, sino que con frecuencia lo es e introduce pecado en la sociedad. Por eso no fueron nada ingenuos sobre las posibilidades de una universidad, sino críticos. Creían que, como cualquiera realidad de seres humanos, la universidad y su instrumento especifico, el saber racional, están también amenazados de pecaminosidad, y que por lo tanto una universidad de inspiración cristiana tiene que ser ante todo una universidad convertida. Y la conversión fundamental consistía en poner todo su peso social a través de su instrumento específico, el saber racional, en favor de las mayorías populares. Eso es lo que pretendieron e hicieron estos hombres: optar universitaria y cris- 
tianamente por los pobres.

Queda, entonces, la permanente lección -quizás puede ser útil en estos días cuando en el Vaticano se está redactando un documento sobre las universidades católicas - de que es posible una universidad cristiana en el tercer mundo, universidad no aislada en una torre de marfil y con corazón de piedra ante el sufrimiento de los pobres, sino universidad encarnada en sus sufrimientos y esperanzas y con corazón de carne. Queda también la permanente lección de que cualquier actividad cristiana, también la universitaria, se hace en presencia del antirteino que se le opone y le hace contra; en el caso de una universidad, en presencia de la mentira. Queda la lección de que no sólo hay que superar la ignorancia, sino combatir y entablar una lucha a muerte contra la mentira. Queda la lección de que -como ocurre siempre, ya desde los profetas y desde Jesús-, afirmar y analizar la verdad es defender a los pobres y por ello enfrentarse a sus opresores. Queda la lección, la más importante y la que dio vida a esos hombres, de que una universidad puede ser la voz de los pobres, puede mantener su esperanza y puede ayudarlos en sus caminos de liberación.

Y queda la lección suprema, la del mayor amor. Trágicamente, a lo largo de toda la historia, quienes anuncian y fomentan el reino de Dios tienen que enfrentarse con el antirreino. No importa que lo hagan como campesinos, obreros, religiosos, sacerdotes, obispos, profesionales o universitarios; todos ellos son perseguidos. También a estos jesuitas universitarios los mataron por defender a los pobres. $Y$ si la magnitud del ataque es proporcional a su identificación con los pobres, entonces puede decirse que muy grande ha sido la defensa que la UCA ha hecho de los pobres.

\section{6. ¿Qué Iglesia nos dejan?}

Hablar hoy de la Iglesia es asunto delicado y aun polémico. Se comprenderá que no es mi intención en absoluto ni es éste el momento de entrar en polémicas ni de defender intereses, sino momento de sinceridad ante Dios y ante nosotros mismos. Por eso, en presencia de sus cadáveres, sólo pretendo ayudar a reflexionar con serenidad sobre el probleme perenne y fundamental, vuelto a poner de relieve por el Vaticano II y Medellín, sobre lo que es la verdadera Iglesia de Jesús y sobre cómo deben ser hoy en nuestro mundo los seguidores de Jesús, los miembros de su cuerpo en la historia.

En la misa de funeral, ante los seis cadáveres, el nuncio de su 
santidad los llamó verdaderos hijos y miembros de la Iglesia. Y les dio el nombre que la Iglesia reserva para sus mejores hijos: mártires. $Y$ tiene toda la razón, porque en verdad fueron eclesiales. He dicho frecuentemente, sin ninguna ironía, sino con sinceridad, que, aunque han abundado conocidamente las tensiones de los jesuitas con algunos miembros de la jerarquía, los jesuitas de Centroamérica hemos crecido en eclesialidad en estos últimos años. Y la razón para esta afirmación es que estamos ahora más integrados dentro del pueblo de Dios, participamos más de su vida real, nos sentimos menos elitistas y triunfalistas y más llevados por la fe, la esperanza $y$ el amor de otros, sobre todo de los pobres del pueblo de Dios. Procuramos también seguir y presentizar mejor a Cristo en la historia, cuyo cuerpo somos, para hacer presente en el mundo a Cristo, sacramento de salvación. Esta es la Iglesia que nos leg6 el Vaticano II y a ella queremos ser fieles. Y Medellín afirmo muy claramente que los pobre spresentan a la Iglesia el mayor desafio, que la Iglesia no puede desoirlo, que tiene que vivir y desvivirse por su liberación total, en un apalabra, que la Iglesia tiene que convertirse y ser Iglesia de los pobres. También a esa Iglesia queremos ser fieles.

Esta es la Iglesia a la que pertenecieron los seis jesuitas, la que representaban también oficialmente en su trabajo estrictamente sacerdotal y, sobre todo, la Iglesia que quisieron construir. En esa Iglesia vivieron y gozaron, pero también sufrieron. Les dolía la Iglesia cuando no estaba a la altura de las circunstancias, cuando miraba más por sí misma y la institución que por el dolor del pueblo, cuando varios de sus jerarcas mostraban incomprension e indiferencia ante el sufrimiento del pueblo y rechazaban sus mejores aspiraciones, cuando -incomprensiblemente - silenciaban a Monseñor Romero. Pensaban, en conjunto que la Iglesia pasa por un proceso de involución, que poco a poco se ha querido silenciar al Vaticano II, a Medellín, a Monseñor Romero, a las comunidades eclesiales de base, a la vida religiosa en América Latina. ¡Y cuánto sufrieron por ello! Por eso también eran críticos, dentro de la Iglesia, por supuesto, con libertad y madurez, y pensaban que la denuncia profética al interior de la Iglesia era un gran e insustituible servicio a ella misma, mientras que la adulación y el servilismo -que siempre son premiados- es un grave mal que se le hace a la Iglesia. En una palabra, se sabían Iglesia, deseaban lo mejor para la Iglesia y, sobre todo, deseaban y trabajaban por construir la mejor Iglesia para el pueblo salvadoreño.

Si recuerdo ahora estas cosas es para que su martirio nos ayude a todos a esclarecer y solucionar un problema eclesial serio que lejos 
de desaparecer va en aumento. Desde hace algunos años, en América Latina sobre todo, ha vuelto a salir a la superficie un viejo problema: cuál es la verdadera Iglesia. No se habla ahora de ello en términos dogmáticos, por supuesto, pero sí en términos operativos. No está muy claro qué nombre actualizado se le pone hoy oficialmente a la verdadera Iglesia, pero éste suele ir en la línea de la "comunión," entendida eficazmente como sumisión de abajo hacia arriba. $Y$ se recalca, con verdad, su "misterio," pero con menoscabo y sospecha de llamarla "pueblo de Dios." De esta forma, realmente, se favorece que la Iglesia pueda, en cuanto Iglesia, desentenderse de lo que está abajo en la historia, de los pobres, que pueda desentenderse de buscar en ellos inspiración, el espíritu de las bienaventuranzas, la luz que proviene del siervo sufriente de Yahvé. Y así, aunque haga cosas buenas en su favor, favorece el no hacer de los pobres algo central dentro de la Iglesia, ni el desvivirse por ellos su misión central.

Por otra parte, en América Latina se ha creado la expresión "Iglesia de los pobres," Iglesia que hace central en su misión y su configuración a los pobres de este mundo. Pues bien, de esta Iglesia de los pobres se sospecha, y cuando se la llama "Iglesia popular," es para designar formas peligrosas y equivocadas de ser Iglesia, para desacreditarla o condenarla. Eso lo sabemos todos y muchos sufrimos por ello. Sufrimos porque se la condena muchas veces sin conocerla bien $y$ sin dialogar con ella. Y sufrimos sobre todo porque no se reconoce ni se acepta agradecidamente que esa Iglesia de los pobres, con todas sus limitaciones y errores, esta produciendo mucha fe, mucha esperanza, mucho amor y mucho martirio.

Todo esto lo digo ahora sin acritud y con la esperanza de que estos seis nuevos mártires, junto a tantos otros, nos hagan reflexionar a todos. Estos jesuitas asesinados gozaron de la amistad y del respeto de algunos - muy pocos- hermanos obispos. Ciertamente fueron amigos intimos y colaboradores muy cercanos de Monseñor Romero y con frecuencia han colaborado fraternalmente con Monseñor Rivera. Obispos como don Pedro Casaldáliga han estado en nuestra casa y en ella se han sentido como en su casa. Obispos católicos y de otras iglesias hermanas protestantes nos han visitado en la UCA y hemos departido fraternalmente, cristianamente, como miembros, todos, del pueblo de Dios y de la Iglesia de Jesús, cada uno con su función y su carisma específico. Pero de alguna forma, estos jesuitas eran también vistos como miembros y representantes supuestamente de una Iglesia peligrosa, poco obediente, sospechosa, quizás hasta poco ortodoxa. En su trabajo pas- 
toral sacerdotal eran aceptados en la arquidiócesis y algunos de ellos eran invitados, excepcionalmente, a dar charlas y retiros a los sacerdotes. Pero en conjunto, no eran muy bien vistos por muchos obispos en El Salvador y en el área centroamericana. Sus ideas, su teología, su compromiso estaban bajo sospechas. Ni Ignacio Ellacurra, ni Amando López, ni Juan Ramón Moreno - por citar a los tres que eran teólogos de profesión- eran habitualmente invitados a ofrecer sus reflexiones teológicas, útiles para los graves problemas del paŕs y del área centroamericana. Un obispo salvadoreño, ya retirado, nos acusaba públicamente a los jesuitas de la UCA de ser los causantes de todos los males, incluida la violencia, en el pars. Por prudencia, en algunos casos, por positivo rechazo o desacuerdo con ellos en otros, estos hombres que tenían mucho que aportar a la Iglesia eran ignorados y a veces hasta atacados dentro de la institución. Caía sobre ellos la sospecha de pertenecer a eso que se ha dado en llamar la "Iglesia popular" o de ejercitar el también llamado "magisterio paralelo."

De nuevo, sin ninguna acritud ni amargura, desearia que estos martirios - junto a los de tantos otros cristianos - nos hicieran reflexionar sobre este candente problema actual latinoamericano de cuál es la verdadera Iglesia de Jesús... Para determinarla, se podrán y deberán usar varios criterios: la comunión con la jerarquía, la formulación ortodoxa de la fe... Pero sería peligroso y en el forndo absurdo que no se usaran también otros criterios más primarios y más fundamentales, allí donde se juega la sustancia eclesial. ¿No habrá verdadera Iglesia allí donde -además de la comunión de abajo hacia la jerarquía- se da la comunión de arriba hacia el pueblo de Dios, hacia los pobres de este mundo, los verdaderos privilegiados de Dios? ¿No habrá verdadera Iglesia allá donde - además de las tradicionales prácticas sacramentales y apostólicas- se da una decidida evangelización a los pobres, la comunicación y puesta en práctica de la buena nueva de Dios para ellos, el compromiso solidario con ellos hasta participar de su cruz? ¿No habrá verdadera Iglesia allí donde -además de la obediencia y fidelidad a lo que nos ha transmitido la tradición- se da la obediencia y fidelidad primaria a la actual voluntad de Dios, que lleva hasta a dar la vida?

He formulado todo esto en forma de pregunta retórica, pues la respuesta es evidente. No hay que elegir entre las cosas que he mencionado, pero es importante recalcar dónde está la primariedad. Servir a la Iglesia y a la Iglesia jerárquica es importante para un cristiano y para un jesuita, por supuesto, y estos jesuitas lo hicieron 
siempre que se les pidió algún trabajo. Pero no hay que olvidar algo más obvio y más fundamental: que la Iglesia es sacramento de algo mayor que ella misma, sacramento del reino de Dios y del Dios del reino. El último servicio no puede ser a la Iglesia, sino, en la Iglesia a Dios y a los pobres, porque Dios es mayor que la Iglesia y los pobres, el comunicarles la buena noticia, es la razón de ser de la Iglesia, como lo dijo bellamente Pablo VI en su exhortación Euangelii Nuntiandi.

Esto produce tensiones, como todos sabemos que hay que vivir con honradez, entereza, caridad y esperanza. Pero no debiera hacernos perder lucidez. Se sirve y se ama en verdad a la Iglesia cuando, dentro de ella, se la descentra hacia el reino de Dios, cuando se hace de ella sacramento de algo mayor que ella misma, cuando se hace de ella signo del reino de Dios y realidad toda ella volcada a los pobres de este mundo para quienes es el reino de Dios. Esto es lo que ilustra la vida eclesial de estos jesuitas y de muchísimos otros, y éste es, aunque muchos no quieran aceptarlo, su mejor aporte a la Iglesia. Esto los hace incómodos, ciertamente, pero la sacudida que operan dentro de la Iglesia no es para destruirla, como se ha llegado a decir, ni para debilitarla ni para atacarla. Más bien, al contrario, es para ayudarla a ser mejor Iglesia de Jesús.

A esta Iglesia, como he dicho, se la suele llamar Iglesia de los pobres $y$, peyorativamente, Iglesia popular o Iglesia paralela. No quisiera negar ahora que no hay exageraciones y errores en esta forma de ser Iglesia, excesiva politización a veces o dependencia de movimientos politicos populares, en algunos casos; lo cual ocurte más entre algunos de sus dirigentes que entre los cristianos sencillos que forman las comunidades de base. De hecho, también en las publicaciones de la UCA se ha abordado ese problema y se ha criticado a veces lo que parecía criticable.

Pero dicho todo esto, admitiendo las limitaciones y equivocaciones de la Iglesia de los pobres, hay algo que no se puede ignorar y sería peligroso y nocivo ignorar, incluso para la misma Iglesia institucional. Esta Iglesia de los pobres es la Iglesia más activa y creative, es la más comprometida con les justas causas populares, es la que mejor fomenta la comunidad para superar el endémico mal del individualismo, aunque sea el religioso, la que genera más esperanza para superar la resignación, la que mejor unifica lo salvadoreño y lo cristiano, y ciertamente la que genera más misericordia, más justicia, más compromiso y máa amor al pueblo sufriente. Si de buscar criterios se trata para saber cómo anda la Iglesia, no se pueden ignorar estas realidades. Y lo que no se puede 
ignorar es que esta Iglesia ha sido perseguida con ferocidad sin igual, ha derramado generosamente su sangre $y$ ha producido innumerables mártires que son la verificación del amor mayor. $Y$ si el final de la vida es lo que dice la verdad más profunda sobre la vida misma, no se puede negar que en esta forma de ser Iglesia ha habido mucho de cristiano. Si tantos han muerto como Jesús, es que muchos han vivido como Jesús. Esto es lo que ilustra la vida y la muerte de Monsefior Romero, de los sacerdotes y las religiosas asesinados, de tantos sencillos cristianos, catequistas, predicadores de la palabra, miembros de las comunidades de base, y ahora de estos seis jesuitas.

Sería trágico para la construcción del reino de Dios y para la construcción de la verdadera Iglesia tomar como criterio de verdad lo que es importante, pero secundario, y desdeñar lo que es primero y esencial. Todos lo sabemos, pero hay que recordarlo. El Salvador y toda América Latina han dado muestras de una increible fe y de un increíble amor. Son muchísimos los mártires en nuestros países, y si ese amor mayor no es criterio de verificación de verdadera Iglesia, puede uno preguntarse qué lo será. Recordemos que no todos en la Iglesia han sido perseguidos, sino que muchos han sido favorecidos y halagados por los opresores. Han sido perseguidos aquellos que se han parecido más a Jesús y, como él, han optado en verdad por los pobres. Y por ello la persecución no conoce denominaciones: católicos, luteranos, episcopalianos, bautistas, menonitas... todos ellos han sufrido persecución cuando se han puesto al servicio de los pobres.

Digamos para terminar que estos jesuitas asesinados sentían muy en su carne a la Iglesia. ¿No será hora, en presencia de esta nueva sangre derramada, de la sangre de tantos sacerdotes y religiosas en América Latina, en presencia sobre todo de la sangre derramada por tantos cristianos de las comunidades en América Latina, de reafirmar la Iglesia de los pobres? Es urgente y necesario, para bien de los pobres y de la misma Iglesia, replantear con serenidad, con verdad y con justicia, esta situación anómala que una Iglesia más comprometida y martirial es sospechosa, mientras que los grupos eclesiales poco comprometidos y nada perseguidos para nada son sospechosos. Es urgente y necesario el diálogo intraeclesial, sereno y fraternal, al interior de la Iglesia, con la honradez de todos para reconocer los fallos propios, y con la apertura de todos al amor de los que han derramados su sangre. A ellos se lo debemos y desde ellos podremos construir una Iglesia que es verdadera comunión y verdadera Iglesia de los pobres. 


\section{7. ¿Qué teología nos dejan?}

Digamos también una palabra sobre la teología de la liberación. Se comprenderá que no es éste momento para defender mezquinamente los propios intereses, sino momento para reflexionar a fondo sobre la verdad de las cosas y de la teologia La reflexión la sugiere y la impone el que uno de los asesinados, Ignacio Ellacuría, fue un reconocido teólogo, y también lo fueron Amando Lopez y Juan Ramón Moreno. Todos ellos intentaron hacer teología de la liberación. Y para captar lo que de luminoso para la teologia tiene su martirio recordemos el tipo de objeciones que suele hacérsele, de nuevo sin énimo de polémica, sino con reflexión serena.

Esta teología, como es sabido, ha sido criticada desde hace mucho tiempo; y, afortunadamente, los primeros que la criticaron fueron los poderosos de este mundo. Con gran clarividencia -desde sus propias perspectivas - ha sido duramente criticada y atacada ya desde el informe Rockefeller hasta el informe de Santa $\mathrm{Fe}$, de los asesores de Reagan. También ha sido criticada, después por el CELAM y por el Vaticano en su primera instrucción, aunque éste mitigase su crítica en la segunda. Todo esto es conocido y no voy a insistir en ello, pues ya se ha respondido abundantemente e Ignacio Ellacurfa escribió un largo y excelente artículo en respuesta a la primera instrucción.

Quisiera, más bien, referirme ahora a otro tipo de acusaciones que se hacen a la teologia de la liberación, algunas de ellas con buena intención, otras con desconocimiento de causa y otras con total incomprensión, más bien como autodefensa ante los cuestionamientos de esa teología. De esta manera nos introduciremos mejor, creo yo, en lo más específico de la teología de la liberación.

Dicen unos que la teología de la liberación es insuficientemente científica, que está animada por la fe, sí, pero que es poco crítica y hasta ingenua. Dicen otros, en sentido contrario, que la teología de la liberación es, en el fondo, elitista, cosa de pensadores de escritorio que no llega a las mayorías. Y muchos dicen, o quisieran decir, que la teología de la liberación ya ha dado de sí todo lo que podía, que ya ha pasado de moda. Creo que en estas críticas hay alguna o mucha verdad, según los casos, pero no aparece toda la verdad ni la verdad más importante de la teología de la liberación. En cualquier caso, no aparece la verdad de la teología de la liberación tal como la entendían y practicaban estos jesuitas.

Verdad es que la teología de la liberación debe progresar en conocimientos de todo tipo, en autocrítica intelectual, en capacidad de sistematización. Y en ello insistía mucho Ignacio Ellacuría, genial 
pensador a quien no se le podía acusar de no valorar el componente intelectual de la teologia. De hecho, muchas veces en la UCA hemos pedido a té́logos de otras latitudes que nos ayuden con el inmenso capital que tienen de conocimientos toológicos, de bibliotecas y tiempo, de los que aquí carecemos -y recuérdese que, simbolicamente, también la biblioteca de teología del Centro Monseñor Romero fue parcialmente destruida después de cometer los asesinatos. Mucho agradecemos a los teólogos que nos han acompañado en todo esto, especialmente a los téblogos jesuitas, y no jesuitas, que han venido de España a aportar aquello de lo que nosotros carecemos, incluso con algunes críticas suyas positivas y cariñosas, y también a aprender -así lo repiten-a hacer teologia en El Salvador.

Pero dicho todo esto, todavia esté por ver qué teologia, de las académicas y científicas, ha recogido lo fundamental de la Escritura y del Evangelio, de la actual palabra de Dios en el hoy de la historia, si es que se cree que Dios todavía sigue hablando hoy a sus creaturas, qué teología ha dado respuesta al mayor problema de la humanidad de hoy que es el viciamiento de la misma creación de Dios a causa de la pobreza, la opresión y la muerte, qué teologra ha unificado en su propio quehacer fe y justicia, teoría y praxis, qué teologia ha unificado teología y espiritualidad -opción por los pobres. De nuestras limitaciones somos bien conscientes, y toda ayuda y toda crítica es cordialmente bienvenida. Pero sería empobrecedor y erróneo para los críticos académicos de la teología de la liberación ignorar la novedad y el aporte estrictamente intelectual de ésta, su capacidad de redescubrir cosas absolutamente fundamentales de la revelación de Dios que, en las teologlas académicas y científicas, han dormido el sueño de los justos durante siglos, su replanteamiento de lo que es conocer teológicamente, de la verificación de las verdades teológicas, etc. Esto lo ha hecho insignemente Ignacio Ellacuría: que la teologia tome en serio lo signos de los tiempos para que la teología sea elevar la realidad a concepto teológico, comprender la teología como la teoría de una praxis histórica y eclesial (personalmente lo he reformulado afirmando que la teología es intellectus amoris, misericordiae, justitiae).

Se puede discutir honestamente si la teología de la liberación tiene muchos saberes, saberes en plural, $y$ se puede exigir, ciertamente, que estos saberes se sistematicen mejor. Pero estoy convencido que ofrece a todos un saber fundamental acerca de Dios y acerca de este mundo realmente verdadero, serio, razonado y argumentado, y, si se quiere, científico. $Y$, en cualquier caso, al me- 
nos para aquellos hermanos jesuitas que quieren hacer teologia, la teologia de estos jesuitas, teología de la liberación, muestra que es la toologia más ignaciana en el mundo de hoy, pues está guiada por la búsqueda de la voluntad de Dios hoy, para ponerla en práctica, y por el seguimiento de Jesús hoy, pobre y humilde.

Verdad es también, como dicen otros, que la teologia de la liberación no llega, en cuanto teología formulada técnicamente, a las mayorias populares, que normalmente no conocen ni siquiera el nombre de esa teologia ni de ninguna otra. Si se quiere, la teologia de la liberación es hecha por "profesionales." Pero nada de esto implica que sea elitista, hecha en un escritorio para élites que la leen después en sus escritorios.

La teología de la liberación no es -directamente-masiva y popular, como no lo es ninguna de las teologias convencionales, pero se relaciona muy específicamente con lo popular y masivo porque recoge la verdadera realidad de las mayorías populares, ciertamente su pobreza, su sufrimiento y su esperanza; más aún, recoge muchas de las reflexiones y teologlas populares de las comunidades. Los que recogen la realidad son pocos, élite; pero la realidad recogida es la de muchos, la de los pobres. Ignacio Ellacuría repetía que se hace teologia sentado en un escritorio, pero no se hace desde un escritorio, sino desde los pobres. Y a ellos se les devuelve la verdad teológica descubierta desde ellos, aunque las formas como llega no son las académicas, obviamente, sino los pequeños folletos, las homilías, las reflexiones biblicas de las comunidades, los libros de cantos, etc. Si las mayorias populares, hoy, comprenden un poco mejor que lo que están sufriendo es el pecado del mundo, que Dios es un Dios de los pobres, de ellos, que lo que anunció Jesús es un reino de vida y justicia para ellos, que por ello sufrí el destino de los pobres y fue asesinado; si las mayorías populares sienten un poco más de ánimo para trabajar y luchar generosa y noblemente para que la vida alcance a todos, entonces, aún sin haber oído una palabra de la teología de la liberación, ésta les ha llegado.

Verdad es, por último, que la teología de la liberación no puede dormirse en los laureles, que tiene que abordar con mayor seriedad - como lo está intentando hacer- nuevas problemáticas: la religiosidad popular, las religiones indígenas, la mujer, la ecologfa... Pero lo que me suele dejar sin aliento es cuando se repite que la teologia de la liberación ya ha pasado de moda. De nuevo, que tal o cual libro o autor de la teología de la liberación vaya perdiendo actualidad es posible y aun probable, y a medida que pasa el tiempo 
es incluso posible que todos ellos vayen quedando desactualizados. Pero nada de esto significa que la teología de la liberación, como tal, no sea - desafortunadamente- muy actual y muy urgente, y cada vez más actual y más urgente. Don Luciano Méndez, obispo brasileño jesuita, dijo una vez que "la teología de la liberación ha puesto el dedo en la llaga de América Latina." Eso fue verdad entonces y sigue siendo verdad ahora. La opresión en el tercer mundo no es una moda, sino algo muy actual y en aumento. La llaga de América Latina, lejos de curarse, se ensancha y se infecta cada vez más. Como Ellacuría repetía, a Dios no le ha salido muy bien la creación y ésta va a peor, hoy hay más millones de pobres en el mundo que ayer y menos de los que habrá mañana.

Es muy importante pues recordar y mantener lo fundamental: liberación es correlativo a opresión, y la opresión y la injusticia persisten y van en aumento, en forma de creciente empobrecimiento en el tercer mundo, en forma de un mayor e inhumano distanciamiento entre parses ricos y pobres, en forma de conflictos bélicos -más de cien desde la última guerra mundial y todos ellos en el tercer mundo-, en forma de desculturización a través de la imposición de culturas comerciales foráneas... La opresión no es una moda. Los clamores de los oprimidos siguen llegando al cielo y, como dice Puebla, cada vez con mayor vigor. Y Dios hoy sigue recogiendo esos clamores, sigue condenando la opresión y sigue animando a la liberación. Si esto no se capta, no se entiende una palabra de la teología de la liberación. Y lo que me pregunto es sobre qué va a versar la teologia si ignora este hecho fundamental de la actual creación de Dios, cómo va a llamarse a sí misma "cristiana" una teología que pasa por alto la crucifixión de pueblos enteros y su necesidad de resurrección, aunque en sus libros siga hablando de un crucificado y un resucitado hace veinte siglos. Por ello, si quienes hacen teología de la liberación no lo hacen bien, que otros la hagan y la hagan mejor. Pero alguien la tiene que seguir haciendo. Y, por amor de Dios, que no se la llame una moda.

Ojalá llegue pronto el día en que la opresión, la pobreza indigna e injusta, la represión cruel y masiva cesen de existir. Ese dra, la teología de la liberación quedará obsoleta, y por ese día trabajan los téblogos de la liberación, aunque ese día se queden sin oficio. Pero mientras dura la opresión $-y$ todas las estadísticas dan que América Latina va a más pobreza- la teología de la liberación es necesaria y ungente. Es la única teología -0 , por lo menos la única que lo hace con absoluta seriedad- que defiende a los pobres de este mundo. Y, recordemos, es una teologia que tiene mártires, como 
Ignacio de Antioquía y Justino de los primeros siglos, lo cual, como siempre, muestra que al menos ha sido teologia cristiana.

No quisiera que esto que he dicho sonara a exabrupto ni menos a defensa de intereses personales, que poco lugar tienen ahora en mi pensamiento. Sí quisiera que fuera una llamada a la seriedad de la teología. Los cadáveres de los jesuitas muestran que esa teología no es elitista, sino popular, pues ha surgido en defensa del pueblo y se ha sumergido en el destino del pueblo. Muestran que algo serio ha dicho esa teologia, también científica y académicamente, pues no olvidemos que lo más temido de esos hombres ha sido su palabra seria y razonada, su palabra teológica en este caso. $Y$ muestran, en cualquier caso, que la opresión -aquí en forma de cruel asesinatosigue siendo una realidad pavorosa a la cual la teologia tiene que responder y sin responder a ella en vano se llamará cristiana.

\section{8. ¿Qué es lo que queda en verdad?}

Después de estas reflexiones, casi disgresiones, quisiera volver, para terminar, al hecho mismo del asesinato y preguntarme qué es lo que queda en la historia salvadoreña y en el fondo de los corazones de quienes seguimos viviendo. Ya he dicho al principio que este asesinato-martirio ha sido para mí distinto a otros muchos. En otras ocasiones, en las misas de los mártires con sus cuerpos presentes, junto al dolor se palpaba la esperanza e incluso el orgullo y gozo de ser cristiano. Esta vez, las cosas han sido diferentes y la pregunta qué es lo que queda se me ha impuesto de una manera distinta. La respuesta es en este caso muy personal, pero espero que vaya más allá de lo personal y pueda iluminarnos a todos.

Ante todo queda un pueblo sufriente y todavía más desprotegido. Estos asesinatos han acaecido precisamente en una semana de guerra que ha dejado alrededor de mil muertos, incontables heridos, miles de viviendas pobres destruidas y gente pobre que ha tenido que dejar sus casas y buscar refugio, en otros lugares, como tantas otras veces ha ocurrido en el país. Otros tendrán la tarea de analizar política y éticamente la responsabilidad de lo acaecido, lo acertado o equivocado del accionar del FMLN en la ciudad en estos días y de analizar y juzgar de la reacción de la Fuerza Armada. Pero, como siempre, lo que está más claro es que queda un pueblo que, en esta semana, se ha visto todavía más empobrecido, más aterrorizado y que ha visto disiparse todavía más las esperanzas de paz.

En este contexto veo la malicia última de los asesinatos de los jesuitas. Se ha asesinado a quienes defendieron a los pobres y éstos 
quedan todevía más desprotegidos. Y si a estos asesinatos se une la campaña y persecución en estos días contra todas las iglesias - tal como lo ha denunciado Mons. Rosa-, el significado es muy claro: queda ahora un pueblo más desamparado. En estos días se ha asesinado a sacerdotes catolicos, se ha hostigado gravemente a templos llenos de gente que en ellos buscaben refugio, se ha amenazado a Monseñor Rivera y a Monseñor Rosa, y el fiscal de la república ha llegado a pedir a Juan Pablo II que los retire del pafs. Se ha hostigado y capturado a muchos miembros de la Iglesia luterana, de la Iglesia episcopaliana, de las comunidades bautiotas, de la comunidad de los menonitas. Se ha amenazado de muerte, con seriedad, a muchos sacerdotes, cristianos y trabajadores sociales. El obispo Medardo Gómez, de la Iglesia luterana, ha tenido que abandonar el país bajo protección diplomática. El pastor Luis Serrano, máximo dirigente de la Iglesia episcopaliana, sigue preso en los cuerpos de seguridad. Varios sacerdotes católicos y muchos trabajadores religiosos y sociales, pasan ya de 50, han sido forzedos a abandonar el país. Dos semanas después de los asesinatos todavia se sigue hostigando y cateando refugios de la Iglesia. $Y$, por supuesto, se ha pretendido intimidar y anular a la UCA, universidad cristiana.

Lo que se ha pretendido, pues, es desmentelar a la Iglesia de los pobres, quitar a los pobres el amparo, y la defensa que han encontrado en estas iglesias. Y lo que esto significa lo saben muy bien los salvadoreffos. Ya en los años 1977-1980 se intentó desmantelar a la Iglesia en la primera gran oleada de persecución, y todos sabemos la pérdida irreparable que fue el asesinato de Monseñor Romero, de los sacerdotes, religiosas, catequistas, miembros de las comunidades de base... Poco a poco se fueron recuperando $y$ ahora, de nuevo, se vuelve a intentar desmantelar a la Iglesia y con ello su defensa de los pobres. Aquí está el fondo de la cuestión y la malicia última de estos asesinatos: queda una Iglesia diezmada y un pueblo todavia más desprotegido. El asesinato de los seis jesuitas ha sido, ante todo una gran pérdida para los pobres. Y es que, como se ha dicho, antes que la Iglesia hiciera una opción por los pobres, los pobres ya habían hecho una opción por la Iglesia, buscando en ella el amparo y la esperanza que no les venían de ninguna otra parte.

Queda también, no lo trivialicemos, el dolor, la duda, la oscuridad. No hay que sorprenderse ni avergonzarse porque en estos días venga a nuestra mente la desolación de Job ante el silencio de Dios y el grito de Jesús en la cruz: "Dios mí, Dios mío, ¿por qué me has abandonado?" No es fácil encontrar luz $y$ ánimo en esta 
situación de represión y muerte y en esta situación de mayor empobrecimiento y desvalimiento de los pobres. Al menos para mí no ha sido fácil esta vez pronunciar desde el principio las verdaderas y escandalosas palabras que otras veces hemos pronunciado: "los mártires son semillas de vida," "demos gracias a Dios por nuestros mártires." No niego la verdad de estas palabras, pero no me ha sido posible pronunciarlas precipitadamente y menos rutinariamente.

¿Qué es entonces lo que en verdad queda del martirio de estos seis jesuitas? Creo y espero que quede su espíritu, que resuciten, como Monseñor Romero, en el pueblo salvadoreño, que sigan siendo luz en este túnel de oscuridad y esperanza en este país de desventuras sin cuento. Todos los mártires resucitan en la historia y cada uno a su manera. El caso de Monseñor Romero es excepcional e irrepetible, pero también Rutilio Grande está presente en muchos campesinos, las religiosas norteamericanas siguen vivas en Chalatenango y La Libertad, Octavio Ortiz en El Despertar, y los cientos de campesinos martirizados en sus comunidades.

También los jesuitas mártires vivirán en el pueblo salvadoreño. El P. Lolo vivirá sin duda en las escuelas de Fe y Alegría y entre los pobres que lo han querido durante muchos años. No sé como resucitarán los mártires de la UCA A mí me gustaría que el pueblo salvadoreño los recordara como testigos de la verdad, de modo que sigan creyendo que la verdad es posible en el pais; que los recordara como testigos de la justicia - justicia estructural, en palabra fría; amor a las mayorías populares, en palabras más dicentes-, de modo que el pueblo salvadoreño mantenga el ánimo de que es posible cambiar el país; que los recuerde como testigos fieles del Dios de vida, de modo que el pueblo salvadoreño siga viendo en Dios a su Dios defensor; que los recuerde como jesuitas que intentaron la dificil conversión y pagaron el precio por defender la fe y la justicia. Esto es lo que yo espero que estos jesuitas dejen al pueblo salvadoreño y que en ese legado sigan vivos, inspiradores y animantes.

Para la Iglesia, para los creyentes, me gustaría que los recordaran como aquellos testigos de la fe de los que habla la Carta a los Hebreos y, sobre todo, como seguidores del testigo por antonomasia, Jesús; ese Jesús cuya vida es resumida en la Carta como el misericordioso con los desvalidos y como el fiel a Dios. Traducido al lenguaje de la Compañía de Jesús, que los recuerden como los hombres de la justicia - la actual versión de la misericordia- y como los hombres de fe en el Dios de la vida en presencia de la muerte -la actual versión de la fidelidad. En ese legado espero que 
sigan vivos mis hermanos.

Espero también que las generaciones sucesivas, cuando lleguen la paz y la justicia al pais, recuerden que entre quienes la hicieron posible están estos hermanos jesuitas. Espero que las futuras generaciones cristianas recuerden su aporte a hacer una fe y una Iglesia salvadoreña y cristiana, que agradezcan su testimonio de que fe y realidad salvadoreña no se oponen, sino que se potencian, y que reconozcan que de esa forma - por lo que nos toca a nosotros los humanos- estos mártires han garantizado que en El Salvador se transmita la fe en Jesús. Espero, pues, que en el futuro, los salvadoreños cristianos les agradezcan que el paŕs haya llegado a la justicia y haya crecido en la fe.

El precio a pagar por todo ello ha sido muy grande, pero no hay otro. Hoy que tanto se habla de evangelizar las culturas, hay que recordar una evangelización más honda: la evangelización de la realidad, que la realidad llegue a ser buena noticia. Y para ello hay que encarnarse en la realidad como lo dijo Monseñor Romero en palabras que hasta el día de hoy producen escalofríos: "Me alegro, hermanos, de que en este pars hayan asesinado a sacerdotes... Pues sería muy triste que un paŕs en que se está asesinando tan horrorosamente al pueblo no contásemos a sacerdotes entre las víctimas. Es un signo de que la Iglesia se ha encarnado verdaderamente en los problemas del pueblo."

Estas palabras, tan crueles a primera vista, son clarividentes. No hay fe ni evangelización sin encarnación. Y en un pueblo crucificado no hay encarnación sin cruz. Cuántas veces decia Ignacio Ellacuría que lo especificamente cristiano es luchar por erradicar el pecado cargando con él. Ese pecado da muerte, pero cargar con él da credibilidad. Participando en la cruz de los salvadoreños la Iglesia se hace salvadoreña y así se hace creíble. $Y$ aunque a corto plazo, este asesinato es una gran pérdida, a la larga es una gran ganancia: se está construyendo una Iglesia realmente cristiana y realmente salvadoreña. Los cristianos han mostrado realmente que son salvadoreños y asf, los salvadoreños pueden ser realmente cristianos. Y no es éste pequeño fruto de tanta sangre derramada en El Salvador, sangre salvadoreña y cristiana: que la fe y la justicia caminen juntas para siempre.

Nos dejan por último, un grito al mundo entero, que no quiere escuchar estos clamores, que los ignora con facilidad cuendo son los clamores de campesinos anónimos, pero que, esta vez al menos, no ha podido menos de escucharlos. Un grito que es, ante todo, 
denuncia y exigencia a la conversión. "La eangre es la más elocuente de las palabras," decía Monseñor Romero. Las reacciones mundiales -aunque no oé si serán suficientes para detener la tragedia- han hecho pensar a mucha gente. Me dicen que hasta en el Congreso de Estados Unidos recios varones han derramado lágrimas.

Pero nos dejan también una buena noticia, un evangelio. Sobre esta tierra de pecado y de sin sentido se puede vivir como seres humanos y como cristianos. Se puede participar en esa corriente de la historia que Pablo llama la vida en el Espíritu y la vida en el amor, en esa corriente de honradez, de esperanza y de compromiso que una y otra vez pretende ser ahogada, pero que una y otra vez asoma desde lo más hondo de la realidad como verdadero milagro de Dios. Entroncarse en esta corriente de la historia, que es la corriente de los pobres, tiene sus costos, pero anima a seguir viviendo, trabajando y creyendo, ofrece sentido y salvación.

Esto es, creo yo, lo que nos dejan estos nuevos mártires y con esto podemos seguir caminando en la historia, humildemente, como nos dice el profete Miqueas, en medio del sufrimiento y la oscuridad, pero con Dios.

En El Salvador hoy hay mucha más oscuridad que luz y la pregunta por la esperanza no se puede contestar rutinariamente. En una de las cartas que he recibido desde El Salvador me dice una gran cristiana: "De repente me parece que todo ha sido como un sueño y veo a todos nuestros mártires en su trajinar diario. Por los padres estoy tranquila pues sé que están disfrutando de nuestro Padre celestial con sus túnicas blanqueadas con la sangre del martirio, pero pienso en sus familiares y en todos los que aquí quedamos." Cómo seguir con esperanza no es una pregunta rutinaria y cada uno tendrá que dar su propia respuesta. La esperanza parece que lo tiene todo en contra, pero para mí al menos, alli donde veo que ha habido y que hay un gran amor, allí veo que la esperanza renace de nuevo. No es conclusión racional, ni siquiera reflexión teologica. Es simplemente verdad: el amor produce esperanza y un gran amor produce una gran esperanza. Desde Jesús de Nazaret, con muchos antes que él y con muchos después de él, siempre que ha habido verdadero amor, la historia ha seguido adelante, los verdugos han sido perdonados $y$ se les ha ofrecido un futuro, que ojala acepten, y muchos seres humanos y cristianos se han apuntado a esa esperanza. Y junto al gran amor de estos mártires, allí están los rostros de los pobres, en los que el mismo Dios está escondido, pero bien presente, pidiéndonos siempre que sigamos nuestro camino, petición que no podemos desoir. Sigue la historia del pecado y de la 
gracia, sigue la historia de los pobres y sigue la historia de Dios. Seguir adelante en medio de tanta negrura no es nada fácil, pero es algo que nos lo facilitan y nos lo posibilitan los pobres y los mártires. $Y$ es algo que se lo debemos a esos pobres y a esos mártires.

Mis seis hermanos jesuitas descansan ahora en la capilla de Monseñor Romero bajo un gran cuadro suyo. Todos ellos, y muchos más, se habrán dado un gran abrazo y se habrán llenado de gozo.

Nuestro ferviente deseo es que el Padre celestial transmita muy pronto esa paz y ese gozo a todo el pueblo salvadoreño. Y si he escrito estas páginas es en definitiva con la esperenza que el recuerdo de estos nuevos mártires contribuya a la paz, la justicia, el diálogo y la reconciliación de todos los salvadoreños.

Descansen en paz Ignacio Ellacuría, Segundo Montes, Ignacio Martín-Baró, Amando López, Juan Ramón Moreno, Joaquín López y López, compañeros de Jesús. Descansen en paz Elba y Celina, hijas muy queridas de Dios.

Que su paz nos transmita a los vivos la esperanza y que su recuerdo no nos deje descansar en paz.

29 de noviembre de 1989 . 